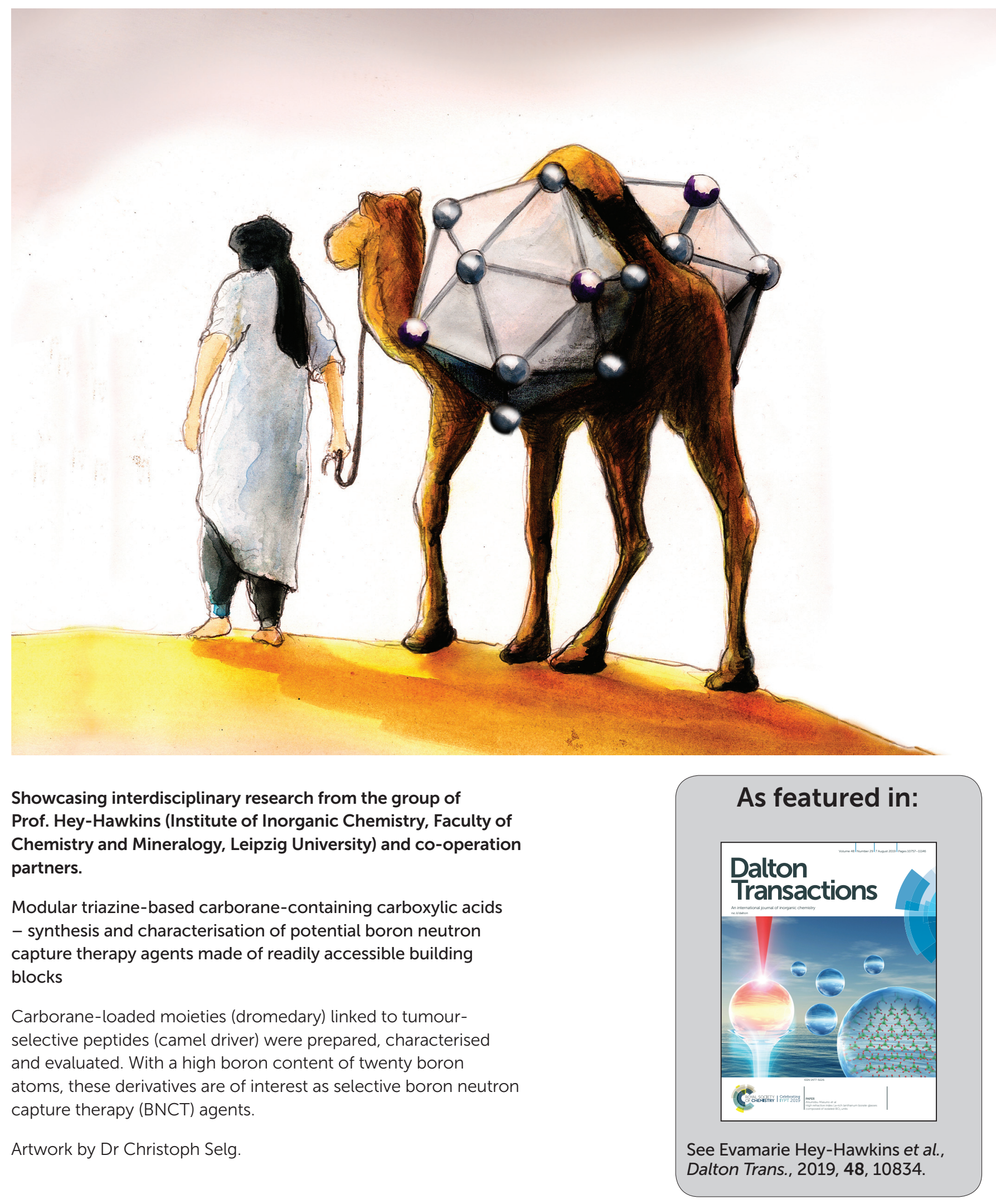

Showcasing interdisciplinary research from the group of

Prof. Hey-Hawkins (Institute of Inorganic Chemistry, Faculty of Chemistry and Mineralogy, Leipzig University) and co-operation

- synthesis and characterisation of potential boron neutron capture therapy agents made of readily accessible building atoms, these derivatives are of interest as selective boron neutron capture therapy (BNCT) agents

Artwork by Dr Christoph Selg
See Evamarie Hey-Hawkins et al. Dalton Trans., 2019, 48, 10834 
(D) Check for updates

Cite this: Dalton Trans., 2019, 48, 10834

Received 20th May 2019,

Accepted 13th June 2019

DOI: $10.1039 / c 9 d t 02130 b$

rsc.li/dalton

\title{
Modular triazine-based carborane-containing carboxylic acids - synthesis and characterisation of potential boron neutron capture therapy agents made of readily accessible building blocks $\uparrow$
}

\author{
Martin Kellert, (D) a Dennis J. Worm, (D) ${ }^{c}$ Paul Hoppenz, (D) ${ }^{c}$ Menyhárt B. Sárosi, (D) a

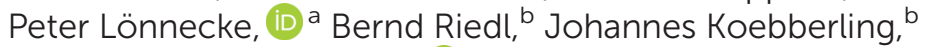 \\ Annette G. Beck-Sickinger (ID) ${ }^{c}$ and Evamarie Hey-Hawkins (D) *a
}

\begin{abstract}
Based on a modular combination of s-triazine, the well-known 9-mercapto-1,7-dicarba-closo-dodecaborane(12) and commercially available carboxylic acids, namely thioglycolic acid, glycine, and $N_{\alpha}$-Boc-Llysine, several carboxylic acid derivatives were synthesised and fully characterised. The thioglycolic acid derivative was introduced into a peptide hormone by solid phase peptide synthesis. High activity and selective internalisation into peptide receptor-expressing cells was observed. With a very high boron content of twenty boron atoms, these derivatives are interesting as selective Boron Neutron Capture Therapy (BNCT) agents.
\end{abstract}

\section{Introduction}

For almost six decades, boron neutron capture therapy (BNCT) has been stated to be a very promising method for cancer treatment. ${ }^{1}$ It combines two non-toxic components, boron-10 containing reagents and thermal or epithermal neutrons, to produce cytotoxic species, which are able to destroy malignant tissue. Boron-10 containing drugs bearing a tumourselective moiety to address the infected site are highly advantageous. ${ }^{2,3-5}$ Ideally, the non-toxic bioconjugate accumulates selectively in the malignant tissues in the required amount of $20-30 \mu \mathrm{g} \mathrm{g}^{-1}$ tumour tissue and can then be irradiated with thermal or epithermal neutrons. ${ }^{5,6}$ It depends on the biomolecule if the BNCT drug is just accumulated in the tumour tissue or internalised into the cancer cells; internalisation of course increases the efficacy of this cancer treatment. ${ }^{7,8,9-16}$ The particles which are generated on neutron capture are lithium and helium nuclei ( $\alpha$ particles) with a high linear energy transfer (LET). ${ }^{5,17}$ These high-energy particles have

\footnotetext{
${ }^{a}$ Leipzig University, Faculty of Chemistry and Mineralogy, Institute of Inorganic Chemistry, Johannisallee 29, 04103 Leipzig, Germany.E-mail: hey@uni-leipzig.de ${ }^{b}$ Bayer AG, Aprather Weg 18A, 42113 Wuppertal, Germany

${ }^{c}$ Leipzig University, Faculty of Life Sciences, Institute of Biochemistry, Brüderstrasse 34, 04103 Leipzig, Germany

$\dagger$ Electronic supplementary information (ESI) available: Crystallographic data of compounds 1, 3, 4, 5, 7 and 8 (CCDC 1898709-1898715), synthetic procedures and characterisation of $\mathbf{1}$ and $\mathbf{2}$ as well as by-products 7 and $\mathbf{8}$; theoretical calculations for formation of 7 and 8. For ESI and crystallographic data in CIF or other electronic format see DOI: $10.1039 / \mathrm{c} 9 \mathrm{dt} 02130 \mathrm{~b}$
}

a mean free path of about 5 to $10 \mu \mathrm{m}$, and thus a limited radius of destructive action. ${ }^{3-5}$ While the combination of suitable boron-rich molecules with tumour-selective biomolecules opens up a very selective tumour therapy which only affects malignant tissue and spares normal tissue, ${ }^{7,9,11-14,18}$ there are still some major challenges, including, but not limited to, the selectivity of the chosen biomolecules for a specific type of tumour, the required high concentration of boron-10 in the cancer cell, the water solubility of the final bioconjugate, and the neutron beam quality, ${ }^{19}$ which are the focus of recent studies. ${ }^{10,14-16,20,21}$

Some ortho- and meta-carboranyl $s$-triazine derivatives were previously synthesised as potential BNCT agents (Chart 1). However, these compounds show only limited water solubility and cellular boron uptake due to unspecific accumulation, caused by the lack of tumour-selective moieties. ${ }^{22-28}$

Another derivative, reported by Ronchi et al., with a $\beta$-D-glucose substituent, an ortho-carborane cluster and a cysteine moiety (Chart 1 ) is remarkably water-soluble and has an amino acid function suitable for coupling reactions with biomolecules. However, the number of synthetic steps required to prepare this compound is rather high ( 8 steps); thus, the overall yield tends to be very small. ${ }^{29}$

Here, we present a modular system based on $s$-triazine, where readily accessible starting materials are combined with meta-carboranes to boron-rich compounds, which can be easily coupled with suitable biomolecules to generate promising BNCT agents. We used a neuropeptide Y (NPY) analogue that selectively binds to the human $\mathrm{Y}_{1}$ receptor $\left(\mathrm{hY} \mathrm{Y}_{1} \mathrm{R}\right)$, which is highly expressed on breast cancer cells. ${ }^{30,31}$ 


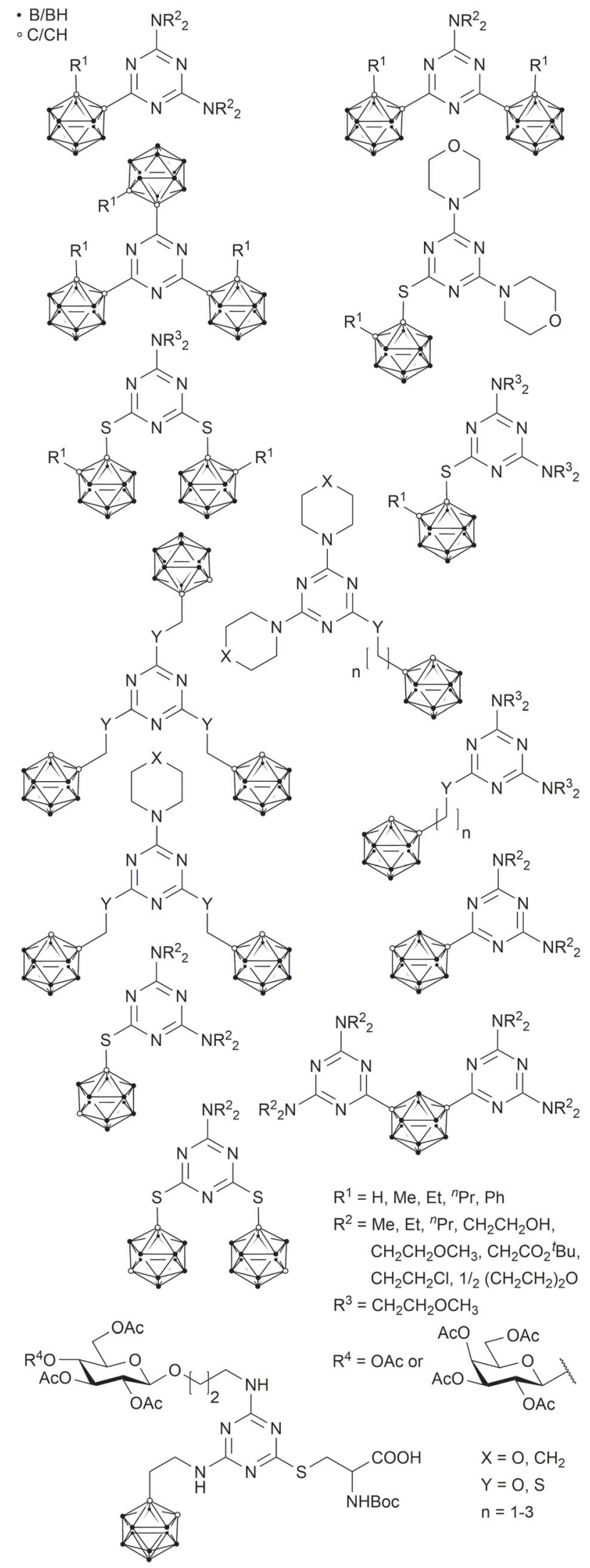

Chart 1 Known s-triazine-based carborane derivatives. ${ }^{22-28,31}$

\section{Results and discussion}

The modular system is based on three components (Fig. 1).

The first component, 1,3,5-triazine or $s$-triazine, is widely used, not only in biologically active compounds. ${ }^{32,33-35}$ It is easily obtained by substitution reactions of cyanuric chloride; the substitution pattern can be controlled by stoichiometry, temperature and the respective nucleophile. ${ }^{33-35,36,37}$ Several carborane-containing $s$-triazine derivatives have been prepared, also as potential BNCT agents (Chart 1). ${ }^{2,23,25-29}$

The second component are meta-carborane (1,7-dicarbacloso-dodecaborane(12)) derivatives. One problem with orthocarborane derivatives is their facile deboronation under basic conditions. $^{38-40}$ Therefore, we have employed meta-carborane which is much more stable under basic conditions in aqueous media, with a special focus on 9-substituted metacarboranes. $^{38,39,41,42}$ 9-Mercapto-1,7-dicarba-closo-dodecaborane(12) has a highly nucleophilic thiol group due to the electron-withdrawing character at the 9-position, ${ }^{14,42-45}$ and was therefore favoured over 1-mercapto-meta-carborane in this approach. This substitution pattern also allows further functionalisation at the cluster carbon atoms for tuning of specific properties, such as water solubility or improved selectivity towards specific cancer cell types, or even the introduction of transition metal complexes or other moieties which can be used for imaging or localisation of the administered bioconjugate. ${ }^{45}$ This is an additional advantage in comparison with known carborane-triazine compounds (Chart 1).

The third component are commercially available carboxylic acids with nucleophilic side chains ( $\mathrm{S}, \mathrm{O}, \mathrm{N}$ atoms), such as 2-mercaptoacetic acid (thioglycolic acid), 2-hydroxyethanoic acid (glycolic acid), aminoacetic acid (glycine) and $N_{\alpha}$-(tertbutoxycarbonyl)-L-lysine ( $N_{\alpha}$-Boc-L-lysine). As the $\mathrm{S}, \mathrm{O}$ or $\mathrm{N}$ moiety has a higher nucleophilicity as the respective carboxy-

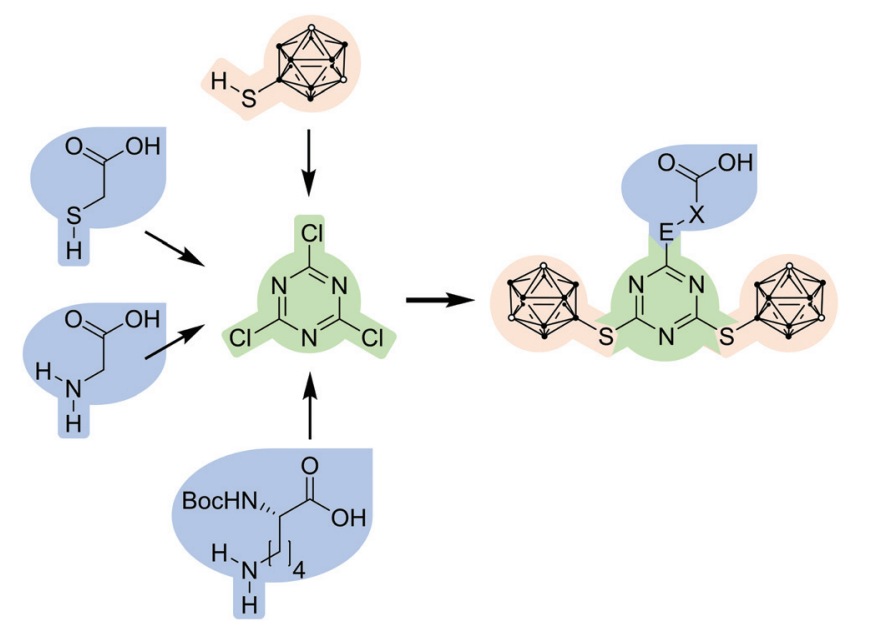

Fig. 1 Combination of a carborane-based building block (pale red) and carboxylic acid derivatives (blue) with cyanuric chloride (green) as a central branching unit and scaffold to give $s$-triazine-based carboranecontaining carboxylic acids $\left(\mathrm{E}=\mathrm{NH}\right.$ or $\mathrm{S} ; \mathrm{X}=\mathrm{CH}_{2}$ or $\left(\mathrm{CH}_{2}\right)_{4} \mathrm{CHNHBoc}$ (Boc $=$ tert-butoxycarbonyl $)$ ). 
late, which is produced under basic conditions, the coupling reaction with the $s$-triazine derivative is straightforward without requiring comprehensive protection strategies; only the $\alpha$-amino group in lysine needs to be Boc protected to avoid undesired side reactions.

\section{Synthesis and characterisation}

9-Mercapto-1,7-dicarba-closo-dodecaborane(12) $(2)^{46}$ is a suitable nucleophile for substitution reactions with cyanuric chloride. $^{42,43}$ The reaction was carried out under inert conditions with $N, N$-diisopropylethylamine (DIPEA) as base (Scheme 1). Attempts to use caesium carbonate and tetra- $n$ butylammonium chloride in tetrahydrofuran were unsuccessful. The substitution ratio was controlled by the stoichiometry $(2: 1)$ and temperature. ${ }^{37}$ The reaction conditions could be optimised to obtain 2-chloro-4,6-bis(1,7-dicarba-closo-dodecaboran-9-ylthio)-1,3,5-triazine (3) in quantitative yield, which is much better than reported for related 1-mercapto-carboranyl substituted $s$-triazine derivatives. ${ }^{25,26}$ The disubstituted $s$-triazine derivative $\mathbf{3}$ is more stable than cyanuric chloride itself and can even be purified by column chromatography. The next step was the replacement of the remaining chloro substituent in $\mathbf{3}$ with a functional group that would allow coupling of the carborane-rich molecule with a tumour-selective biomolecule. For this purpose, glycolic acid, thioglycolic acid, glycine and $N_{\alpha}$-Boc-L-lysine were used to modify 3. After optimisation of the reaction conditions (Table S2, ESI $\dagger$ ), 2-\{[4,6-bis(1,7-dicarba-closo-dodecaboran-9-ylthio)-1,3,5-triazin2-yl] thio\}acetic acid (4), [4,6-bis(1,7-dicarba-closo-dodecaboran9-ylthio)-1,3,5-triazin-2-yl]glycine (5) and $\quad N^{6}$-[4,6-bis(1,7dicarba-closo-dodecaboran-9-ylthio)-1,3,5-triazin-2-yl]- $N^{2}$-(tertbutoxycarbonyl)-L-lysine (6) could be successfully synthesised in moderate to good yields from 3 and thioglycolic acid, glycine, and $N_{\alpha}$-Boc-L-lysine, respectively (Scheme 1). The L-lysine derivative $\mathbf{6}$ is an artificial amino acid and could even be employed directly in peptide synthesis. ${ }^{20}$ However, the synthesis of 2-\{[4,6-bis(1,7-dicarba-closo-dodecaboran-9-ylthio)1,3,5-triazin-2-yl]oxy\}acetic acid by reaction of 3 with glycolic acid was not successful. One possible reason could be the lower nucleophilicity of oxygen in comparison to sulfur and nitrogen. Compounds 3-6 were fully characterised by NMR and IR spectroscopy, and mass spectrometry. Furthermore, single crystals suitable for X-ray structure determination could be obtained of compound 3 from acetone solution, 4 from methanol solution and $\mathbf{5}$ from a mixture of chloroform and acetone.

In the molecular structure of 3 (Fig. 2), one carborane cage is slightly moved out of the ring plane caused by packing effects and intramolecular repulsion between the carborane clusters. The triazine ring is rather distorted with $\mathrm{CNC}$ and NCN bond angles varying from $112.7(1)^{\circ}$ to $114.2(1)^{\circ}$ and $125.6(1)^{\circ}$ to $128.6(2)^{\circ}$, respectively. This is not unusual and was already described for other $s$-triazine derivatives. ${ }^{47}$

In the molecular structure of 4 (Fig. 3), the carborane clusters are slightly moved out of the plane of the triazine ring, as was already observed for 3 . In crystals of 4 , a mixture of car-

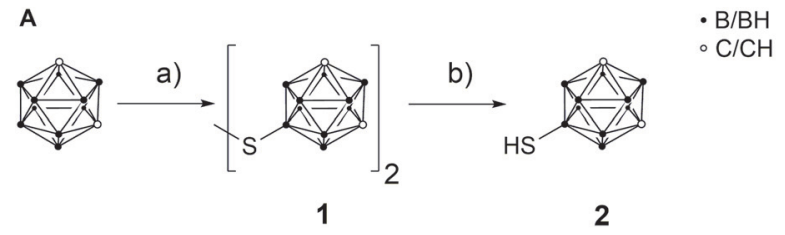

B

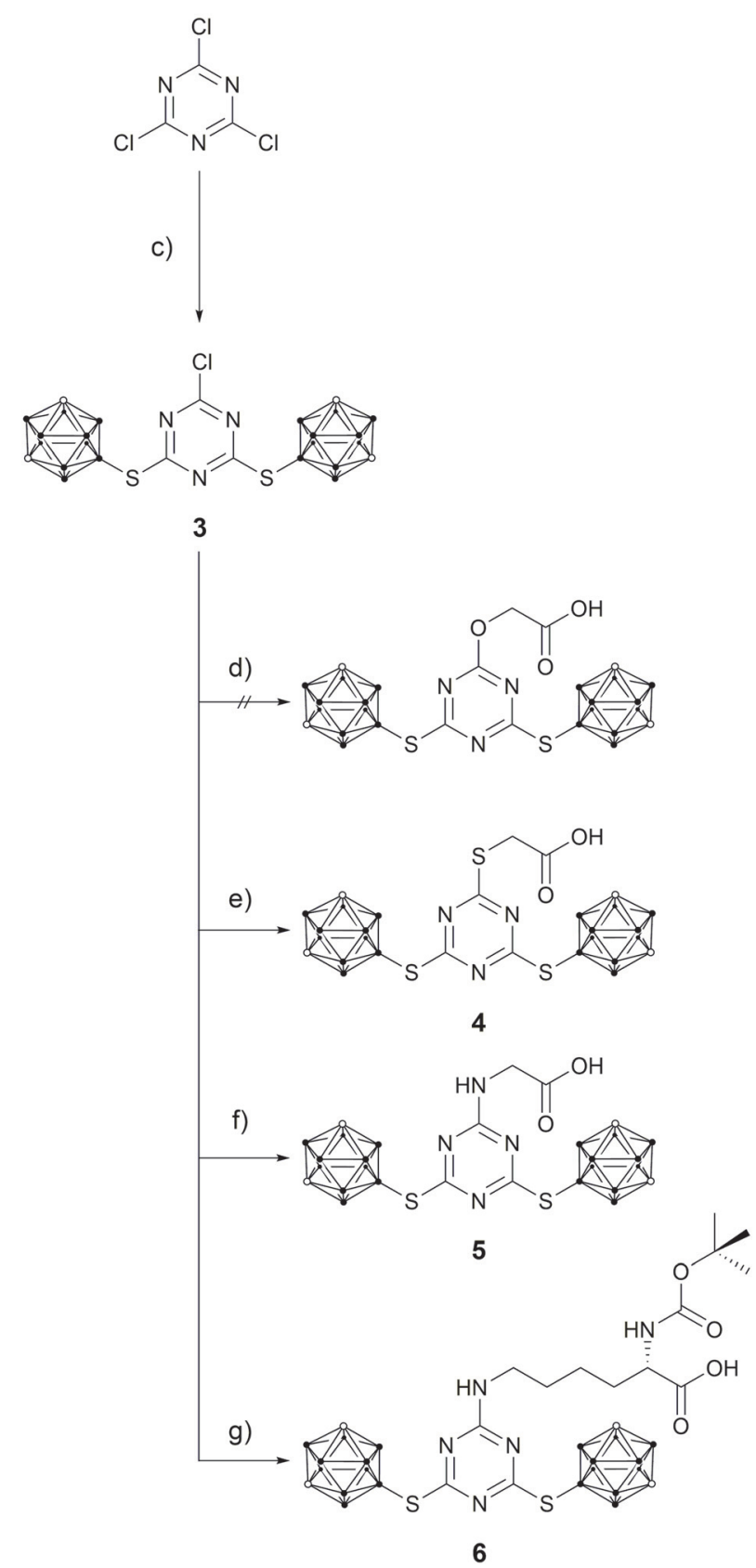

Scheme 1 A: Synthesis of 9-mercapto-1,7-dicarba-closo-dodecaborane(12) (2). (a) $\mathrm{S}_{2} \mathrm{Cl}_{2}, \mathrm{AlCl}_{3}, \mathrm{DCM}, 40^{\circ} \mathrm{C}, 4 \mathrm{~h}$, not isolated; ${ }^{48}$ (b) $\mathrm{Zn}, \mathrm{HCl}$, HOAc, $120{ }^{\circ} \mathrm{C}, 4 \mathrm{~h}, 71 \%{ }^{48} \mathrm{~B}$ : synthetic route to compounds $4-6$. (c) 2, $\mathrm{N}, \mathrm{N}$-diisopropylethylamine (DIPEA), acetonitrile $(\mathrm{MeCN})$, reflux, $5 \mathrm{~h}$, quant.; (d) glycolic acid, $\mathrm{NaOH}, \mathrm{MeCN} / \mathrm{H}_{2} \mathrm{O}$ (1:1.25), $85{ }^{\circ} \mathrm{C}, 18 \mathrm{~h}$, no product obtained; (e) thioglycolic acid, DIPEA, MeCN, reflux, $3 \mathrm{~h}, 27 \%$; (f) glycine, $\mathrm{NaOH}, \mathrm{MeCN} / \mathrm{H}_{2} \mathrm{O} /$ ethyl acetate (EtOAc) $(3.33: 2: 1), 95^{\circ} \mathrm{C}$, $6 \mathrm{~h}, 60 \%$; (g) $\mathrm{N}_{\alpha}$-Boc-L-lysine, $\mathrm{NaOH}, \mathrm{MeCN} / \mathrm{H}_{2} \mathrm{O}(1: 1), 85^{\circ} \mathrm{C}, 6 \mathrm{~h}, 69 \%$. 


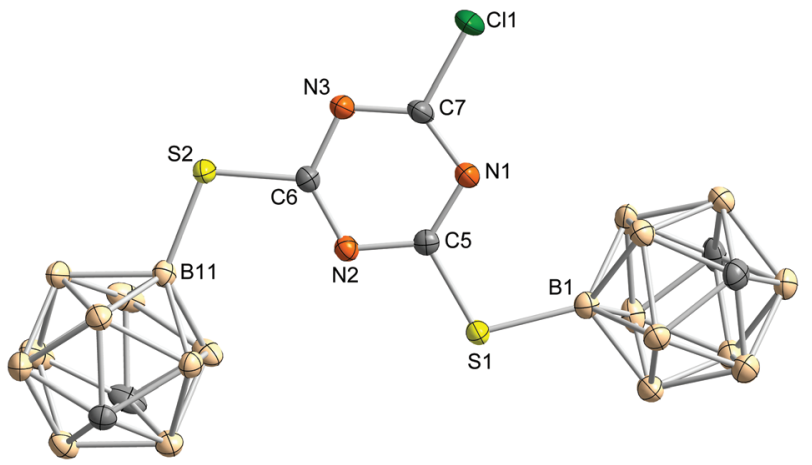

Fig. 2 Molecular structure of 2-chloro-4,6-bis(1,7-dicarba-closododecaboran-9-ylthio)-1,3,5-triazine (3). Hydrogen atoms are omitted for clarity. Thermal ellipsoids are drawn at the $50 \%$ level of probability. Selected bond lengths, distances (pm) and bond angles ( $\left.{ }^{\circ}\right)$ : Cl1-C7 172.7(2), S1-C5 174.2(2), S2-C6 173.4(2), S1-B1 187.2(2), S2-B11 185.9(2), $\cdots \mathrm{N} 10.4$, $\diamond \cdots \mathrm{C} 51.5, \diamond \cdots \mathrm{N} 21.2, \bullet \cdots \mathrm{C} 6 \quad 0.0, \diamond \cdots \mathrm{N} 31.0, \bullet \cdots \mathrm{C} 70.9, \diamond \cdots \mathrm{S} 14.9$, $\diamond \cdots \mathrm{S} 24.3, \diamond \mathrm{Cl} 13.8, \bullet \mathrm{B} 1$ 41.0, $\bullet \mathrm{B} 11$ 1.2; C5-S1-B1 106.1(1), C6S2-B11 107.6(1); represents the mean plane of the triazine core, formed by N1, C5, N2, C6, N3 and C7.

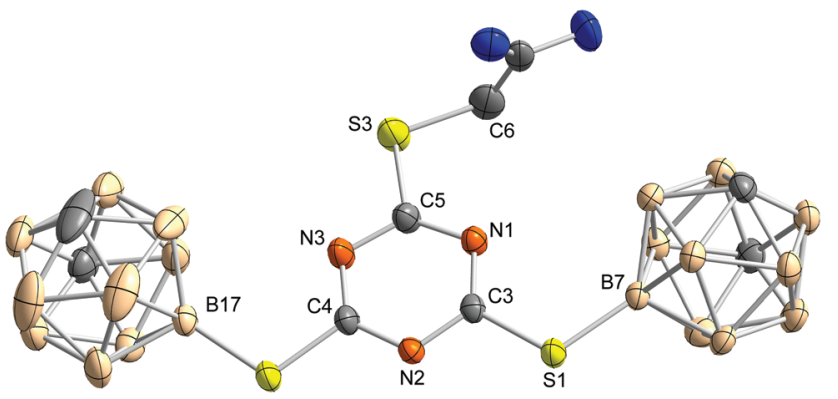

Fig. 3 Molecular structure of 2-\{[4,6-bis(1,7-dicarba-closo-dodecaboran-9-ylthio)-1,3,5-triazin-2-yl]thio\}acetic acid (4) obtained from methanol. Thermal ellipsoids are drawn at the $50 \%$ level of probability. The acid and the methyl ester co-crystallise in a ratio of $0.678(7): 0.322(7)$. Here, only the acid is shown. Hydrogen atoms and co-crystallised methanol molecules are omitted for clarity. Selected bond lengths, distances (pm) and bond angles ( ${ }^{\circ}$ ): S1-C3 174.4(2), S1-B7 186.2(2), S2-C4 174.2(2), S2-B17 186.3(3), S3-C5 173.8(2), S3-C6 177.7(3), - *N1 0.8, $\diamond \cdots \mathrm{C} 30.1, \cdots \mathrm{N} 20.6, \bullet \cdot \mathrm{C} 40.7, \diamond \cdots \mathrm{N} 30.0, \diamond \cdots \mathrm{C} 50.8, \diamond \cdots \mathrm{S} 12.0$,

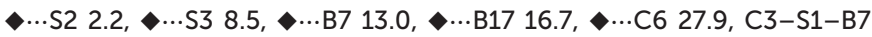
109.9(1), C4-S2-B17 107.0(1), C5-S3-C6 103.5(1); represents the mean plane of the triazine core, formed by N1, C3, N2, C4, N3 and C5.

boxylic acid derivative and methyl ester (ca. 68:32) is present. Apparently, on recrystallisation from methanol, formation of the methyl ester occurred which co-crystallised with the free carboxylic acid.

In the molecular structure of the glycine derivative $\mathbf{5}$, the formation of trimers from three symmetry-independent molecules is observed via hydrogen bonding between the secondary amine group of the glycine moiety and the carbonyl oxygen of the free acid and between the hydroxy group of the free acid and one nitrogen atom of the triazine ring (Fig. 4). Such a trimeric hydrogen-bonded arrangement is unprecedented for triazine derivatives. ${ }^{49}$

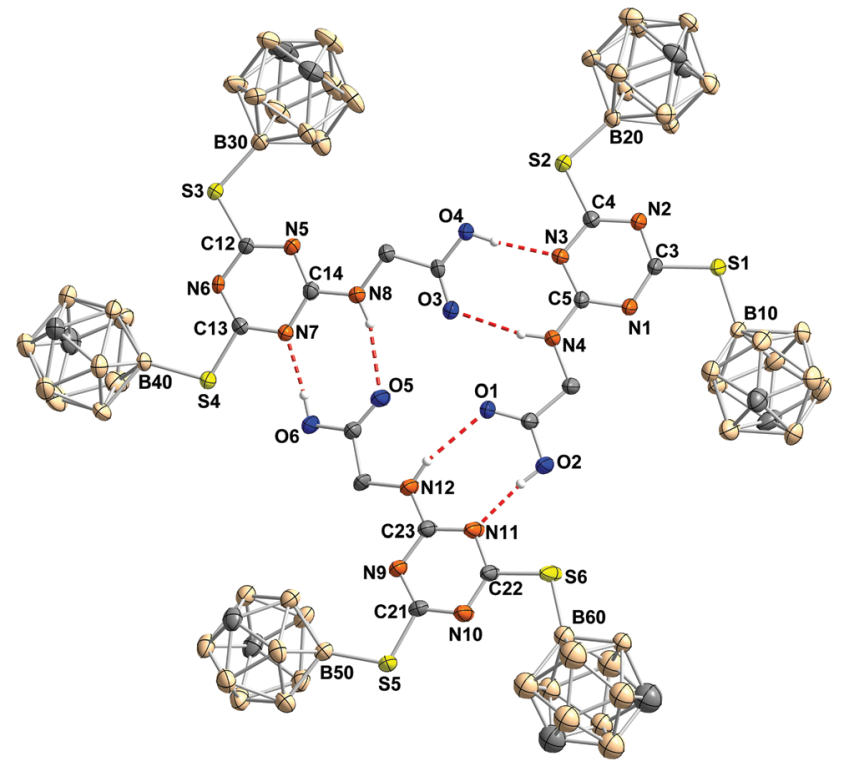

Fig. 4 Arrangement of the three symmetry-independent molecules in 5 viewed along the $a$ axis. Hydrogen atoms, not involved in hydrogen bonding, and solvent molecules are omitted for clarity. Thermal ellipsoids of all non-hydrogen atoms are drawn at the $50 \%$ level of probability; hydrogen atoms have a fixed atom radius of $13.5 \mathrm{pm}$. Selected bond lengths, distances (pm) and bond angles $\left({ }^{\circ}\right)$ : A: S1-C3 175.8(6), S1-B10 187.3(7), S2-C4 175.5(6), S2-B20 185.7(6), N4-C5 133.9(7),

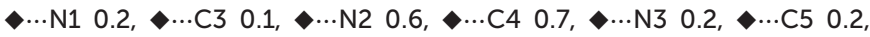

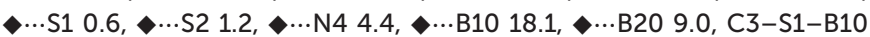
109.2(3), C4-S2-B20 106.7(3), C5-N4-C6 122.0(5); B: S3-C12 174.3(5), S3-B30 185.7(7), S4-C13 175.2(5), S4-B40 186.5(6), N8-C14 132.7(7), $\Delta \cdots \mathrm{N} 51.8, \mathbf{\Delta} \cdots \mathrm{C} 120.9, \mathbf{\Delta} \cdots \mathrm{N} 60.4, \mathbf{\Delta} \cdots \mathrm{C} 130.7, \mathbf{\Delta} \cdots \mathrm{N} 70.3, \mathbf{\Delta} \cdots \mathrm{C} 14$ 1.5, $\Delta \cdots \mathrm{S} 33.1, \mathbf{\Delta} \cdots \mathrm{S} 45.5, \mathbf{\Delta} \cdots \mathrm{N} 8$ 5.8, $\mathbf{\Delta} \cdots \mathrm{B} 3025.2, \mathbf{\Delta} \cdots \mathrm{B} 40$ 30.1, C12-S3B30 107.9(3), C13-S4-B40 105.7(3), C14-N8-C15 122.6(5); C: S5-C21 175.1(6), S5-B50 186.4(7), S6-C22 174.4(6), S6-B60 187(1), N12-C23 $131.1(8), \bullet \cdots N 91.1, \bullet \cdots C 21 \quad 0.4, \bullet \cdots N 10 \quad 1.3, \bullet \cdots C 22 \quad 0.9, \bullet \cdots N 11 \quad 0.6$,

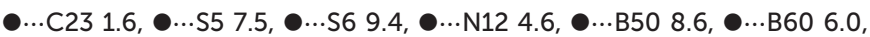
C21-S5-B50 107.8(3), C22-S6-B60 106.4(5), C23-N12-C24 123.3(6); - represents the mean plane of one triazine core, formed by N1, C3, N2, C4, N3 and C5; $\Delta$ represents the mean plane of one triazine core, formed by N5, C12, N6, C13, N7 and C14; represents the mean plane of one triazine core, formed by N9, C21, N10, C22, N11 and C23.

Due to packing effects in the solid state, the trimer of $\mathbf{5}$ does not show $C_{3}$ symmetry. Some atoms are slightly moved out of the mean plane formed by the non-hydrogen atoms which participate in the hydrogen donor-acceptor interactions.

\section{Peptide conjugates and biochemical evaluation}

The carboxylic acid in compounds 4-6 facilitates coupling with tumour-selective biomolecules. One prominent example of a breast tumour-selective peptide is the modified neuropeptide $\mathrm{Y},\left[\mathrm{F}^{7}, \mathrm{P}^{34}\right]$-NPY. It is selective for $\mathrm{G}$ protein-coupled human $\mathrm{Y}_{1}$ receptors, which are overexpressed in breast cancer cells. Importantly, normal breast tissue contains predominantly $\mathrm{Y}_{2}$ receptors. ${ }^{30,31}$ Studies were already carried out for ortho-carborane derivatives which were coupled to $\left[\mathrm{F}^{7}, \mathrm{P}^{34}\right]$-NPY via the primary amino group of lysine- $4 .^{20,48}$ The formation of a 
highly stable peptide bond between the carboxylic acid of boron-rich derivatives and an amino group of the biomolecule of interest (e.g. lysine in specific peptides) is a much-favoured coupling strategy ${ }^{20,48,50-53}$ and was also employed here for the thioglycolic acid derivative 4 . Compound 4 could be incorporated up to three times into the breast cancer-selective peptide $\left[\mathrm{F}^{7}, \mathrm{P}^{34}\right]$-NPY at positions 4,18 and $22 .{ }^{20}$ All conjugates were characterised by RP-HPLC and ESI-MS, verifying the correct composition and excellent purity. Analytical data for $\left[\mathrm{K}^{4}\left(\mathbf{4}^{\prime}\right), \mathrm{F}^{7}\right.$, $\left.\mathrm{K}^{18,22}\left(4^{\prime}\right), \mathrm{P}^{34}\right]$-NPY are exemplarily shown in Fig. 5.

After successful synthesis, all conjugates were tested for their ability to activate and internalise the human $\mathrm{Y}_{1}$ receptor $\left(\mathrm{hY}_{1} \mathrm{R}\right)$. The peptide conjugate with one biscluster $\left(\left[\mathrm{K}^{4}\left(\mathbf{4}^{\prime}\right), \mathrm{F}^{7}\right.\right.$, $\mathrm{P}^{34}$ ]-NPY) exhibits full agonism with an $\mathrm{EC}_{50}$ value of $8.1 \mathrm{nM}$, which is only slightly higher than that of the unmodified control peptide $\left[\mathrm{F}^{7}, \mathrm{P}^{34}\right]$-NPY (Fig. 6A). However, incorporation of more than one derivative 4 in conjugates $\left[\mathrm{K}^{4}\left(\mathbf{4}^{\prime}\right), \mathrm{F}^{7}, \mathrm{~K}^{18}\left(\mathbf{4}^{\prime}\right)\right.$, $\left.\mathrm{P}^{34}\right]$-NPY and $\left[\mathrm{K}^{4}\left(\mathbf{4}^{\prime}\right), \mathrm{F}^{7}, \mathrm{~K}^{18,22}\left(\mathbf{4}^{\prime}\right), \mathrm{P}^{34}\right]$-NPY led to a significant reduction of activity of the peptides at the $\mathrm{hY}_{1}$ receptor. Thus, $\left[\mathrm{K}^{4}\left(4^{\prime}\right), \mathrm{F}^{7}, \mathrm{~K}^{18}\left(4^{\prime}\right), \mathrm{P}^{34}\right]$-NPY can partially activate the $\mathrm{hY} \mathrm{H}_{1} \mathrm{R}$ with an $\mathrm{EC}_{50}>1 \mu \mathrm{M}$, while $\left[\mathrm{K}^{4}\left(4^{\prime}\right), \mathrm{F}^{7}, \mathrm{~K}^{18,22}\left(4^{\prime}\right), \mathrm{P}^{34}\right]$-NPY is inactive. Furthermore, the peptide conjugates were also investigated for their $\mathrm{hY}_{1} \mathrm{R}$ internalisation profile by fluorescence microscopy studies. Without peptide stimulation, the fluorescently labelled $\mathrm{hY}_{1} \mathrm{R}$ (green) was predominantly localised in the cell membrane (Fig. 6B). Stimulation with $100 \mathrm{nM}$ of the native ligand NPY or $\left[\mathrm{F}^{7}, \mathrm{P}^{34}\right]$-NPY for $1 \mathrm{~h}$ led to strong internalisation as observable by the green fluorescence in intracellular vesicles. The mono-substituted conjugate $\left[\mathrm{K}^{4}\left(4^{\prime}\right), \mathrm{F}^{7}, \mathrm{P}^{34}\right]$-NPY was

(

A

NPY:

YPSKPDNPGEDAPAEDLARYYSALRHY INLITRQRY

$\left[\mathrm{F}^{7}, \mathrm{P}^{34}\right]-\mathrm{NPY}$

YPSKPDF ${ }^{7}$ PGEDAPAEDLARYYSALRHYINLITRP ${ }^{34}$ RY

$\left[K^{4}\left(4^{4}\right), F^{7}, P^{34}\right]-N P Y$

YPSK
4.
$4^{4}$

$\left[K^{4}\left(4^{\prime}\right), F^{7}, K^{18}\left(4^{\prime}\right), P^{34}\right]-N P Y$

YPSK ${ }^{4}$ PDF $^{7}$ PGEDAPAEDLK ${ }^{18}$ RYYSALRHYINLITRP ${ }^{34}$ RY

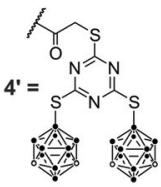

$4^{\prime}$

$4^{\prime}$

$\left[K^{4}\left(4^{4}\right), F^{7}, K^{1822}\left(4^{\prime}\right), P^{34}\right]-N P Y$

YPSK ${ }^{4}$ PDF ${ }^{7}$ PGEDAPAEDLK ${ }^{18}$ RYYK $^{22}$ ALRHYINLITRP ${ }^{34}$ RY

B

C
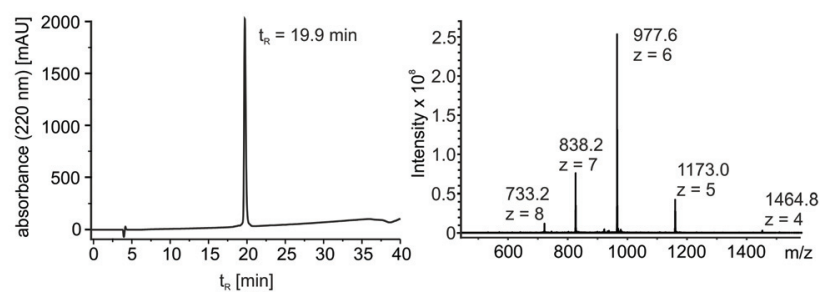

Fig. 5 Sequence of synthesised peptide conjugates and analytical data of $\left[K^{4}\left(4^{\prime}\right), F^{7}, K^{18,22}\left(4^{\prime}\right), P^{34}\right]-N P Y$. (A) Peptide positions 4,18 and 22 were used for modification with 4. (B) Analytical RP-HPLC data of $\left[K^{4}\left(4^{\prime}\right), F^{7}\right.$, $\left.\mathrm{K}^{18,22}\left(4^{\prime}\right), \mathrm{P}^{34}\right]$-NPY. (C) ESI mass spectrum showing multiple charged ion species of $\left[K^{4}\left(4^{\prime}\right), F^{7}, K^{18,22}\left(4^{\prime}\right), P^{34}\right]-N P Y$. MW calc/avg: $5859.6 \mathrm{Da}$.
A

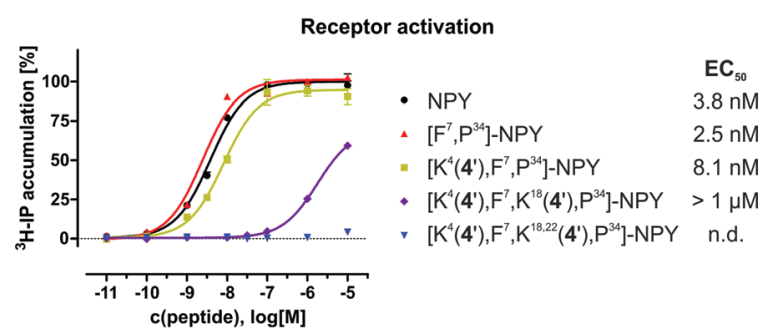

B
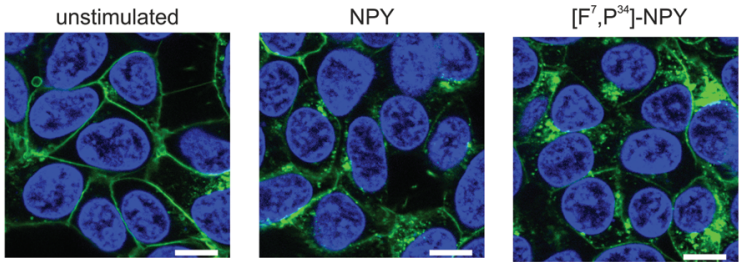

$\left[\mathrm{K}^{4}\left(\mathbf{4}^{4}\right), \mathrm{F}^{7}, \mathrm{P}^{34}\right]-\mathrm{NPY}$
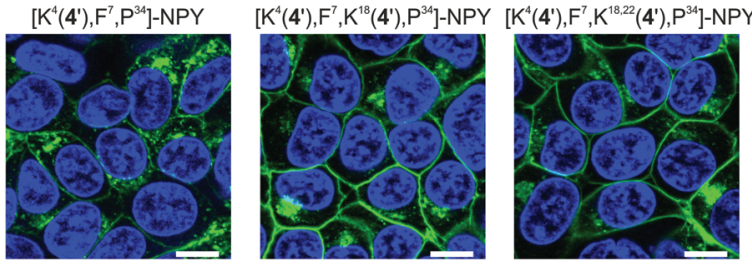

Fig. 6 Receptor activation and internalisation data of modified $\left[\mathrm{F}^{7}, \mathrm{P}^{34}\right]$ NPY. (A) $h Y_{1}$ receptor activation data of synthesised peptide conjugates. Sigmoidal concentration-response curves were determined from at least two independent inositol phosphate (IP) accumulation experiments, each performed in duplicates. (B) Receptor internalisation studies of HEK293 cells stably expressing the $\mathrm{hY}{ }_{1} \mathrm{R}$ fused to eYFP (green). Cells were stimulated with $100 \mathrm{nM}$ peptide for $1 \mathrm{~h}$ at $37^{\circ} \mathrm{C}$ and cell nuclei were stained with Hoechst 33342 (blue). Scale bar: $10 \mu \mathrm{m}$.

also able to internalise the $\mathrm{hY}_{1} \mathrm{R}$ while the conjugates with more than one thioglycolic acid derivative $\mathbf{4}$ were not able to induce internalisation. This is in agreement with their activity.

\section{Experimental section}

\section{Materials and methods}

All reactions were carried out under nitrogen atmosphere using Schlenk techniques, if not reported otherwise. Anhydrous diethyl ether, dichloromethane and tetrahydrofuran were obtained with an MBRAUN solvent purification system MB SPS-800. Acetonitrile was dried over $\mathrm{CaH}_{2}$, distilled and stored over molecular sieve ( $3 \AA$ ) under nitrogen atmosphere. All other solvents were purchased and used as received. 1,2-Di(1,7-dicarba-closo-dodecaboran-9-yl)disulfane (1) and 9-mercapto-1,7-dicarba-closo-dodecaborane(12) (2) were prepared according to the literature procedure. ${ }^{46}$ All other compounds are commercially available.

Thin-layer chromatography (TLC) with silica gel $60 \mathrm{~F}_{254}$ on glass available from Merck KGaA was used for monitoring the reactions. Carborane-containing spots were visualised with a $5-10 \%$ solution of $\mathrm{PdCl}_{2}$ in methanol. For chromatography, silica gel $(60 \AA)$ with a particle diameter in the range of 0.035 
to $0.070 \mathrm{~mm}$ or a Biotage Isolera 1 or a Biotage Isolera 4 automatic purification system with SNAP (particle diameter: 0.040 to $0.065 \mathrm{~mm}$ ) and SNAP Ultra (spherical particle, diameter: $0.025 \mathrm{~mm}$ ) cartridges were used. The triazine and carborane species were detected by an integrated UV/vis detector (Isolera 1) or evaporative light scattering detector (ELSD) A-120 (Isolera 4). For chromatography, solvents were distilled before use.

NMR measurements were carried out on a Bruker AVANCE III HD spectrometer with an Ascend ${ }^{\mathrm{TM}} 400$ magnet at room temperature. Tetramethylsilane was used as internal standard for ${ }^{1} \mathrm{H}$ and ${ }^{13} \mathrm{C}\left\{{ }^{1} \mathrm{H}\right\}$ NMR spectra, and ${ }^{11} \mathrm{~B}$ and ${ }^{11} \mathrm{~B}\left\{{ }^{1} \mathrm{H}\right\}$ NMR spectra were referenced to the $\Xi$ scale. ${ }^{54}$ NMR spectra were recorded at the following frequencies: ${ }^{1} \mathrm{H}: 400.16 \mathrm{MHz},{ }^{13} \mathrm{C}$ : $100.63 \mathrm{MHz},{ }^{11} \mathrm{~B}: 128.38 \mathrm{MHz}$. All chemical shifts are reported in ppm. Assignment of the ${ }^{1} \mathrm{H}$ and ${ }^{13} \mathrm{C}$ signals was based on 2D NMR spectra (H,H-COSY, HMQC, HSQC, HMBC) or selective TOCSY experiments for the lysine derivative. Identification of the boron atom attached to sulfur was possible by comparison of the proton-coupled and -decoupled ${ }^{11} \mathrm{~B}$ NMR spectra. NMR data were interpreted with MestReNova. ${ }^{55}$ NMR signals that appear as broad overlapping signals with the shape of a multiplet in either ${ }^{1} \mathrm{H},{ }^{11} \mathrm{~B}\left\{{ }^{1} \mathrm{H}\right\}$ or ${ }^{11} \mathrm{~B}$ NMR spectra are described as $b^{a}$. IR data were obtained with a PerkinElmer FT-IR spectrometer Spectrum 2000 as $\mathrm{KBr}$ pellets and with a Thermo Scientific Nicolet iS5 with an ATR unit in the range from 4000 to $400 \mathrm{~cm}^{-1}$. Electrospray ionisation mass spectrometry was performed with an ESI ESQUIRE 3000 PLUS spectrometer with an IonTrap analyser from Bruker Daltonics or a MicroTOF spectrometer from Bruker Daltonics with a ToF analyser in negative or positive mode. As solvents for the measurements, dichloromethane, acetonitrile, methanol or mixtures of these solvents were used. Elemental analysis was conducted with a VARIO EL elemental analyser from Heraeus. Melting points were determined with a Gallenkamp MPD350·BM2.5 melting point device.

\section{X-ray diffraction experiments}

Measurements were performed with a Gemini diffractometer (Rigaku Oxford Diffraction) with $\mathrm{Mo}-\mathrm{K}_{\alpha}$ radiation $(\lambda=71.073$ $\mathrm{pm}), \omega$-scan rotation. Data reduction was performed with CrysAlis Pro ${ }^{56}$ including the program SCALE3 ABSPACK $^{57}$ for empirical absorption correction. The structures were solved by dual space methods (SHELXT-2014) ${ }^{58}$ and the refinement of all non-hydrogen atoms was performed with SHELXL-2018. ${ }^{59}$ $\mathrm{H}$ atoms were calculated on idealised positions for 1, 5 and for disordered parts of a structure. In all other cases, $\mathrm{H}$ atoms were located on difference Fourier maps calculated at the final stage of the structure refinement. Structure figures were generated with ORTEP, ${ }^{60}$ Diamond $^{61}$ or Mercury 3.9. ${ }^{62}$ CCDC 1898709 (1), 1898710 (3), 1898711 (4), 1898712 (5), 1898713 (7), 1898714 (8-acetone) and 1898715 (8-methanol)† contain the supplementary crystallographic data for this paper.

2-Chloro-4,6-bis(1,7-dicarba-closo-dodecaboran-9-ylthio)-1,3,5triazine (3). A $500 \mathrm{~mL}$ two-necked round bottom flask equipped with a condenser was charged with $5.00 \mathrm{~g}$ (28.4 mmol, 2.00 eq.) 2 and $2.62 \mathrm{~g}$ (14.2 mmol, 1.00 eq.) cyanu- ric chloride. The flask was evacuated and purged with nitrogen three times. $200 \mathrm{~mL}$ dry acetonitrile were added to this mixture and the suspension was cooled to $0{ }^{\circ} \mathrm{C}$. Subsequently, $6.04 \mathrm{~mL}$ (4.59 g, $35.5 \mathrm{mmol}, 2.50 \mathrm{eq}$.) diisopropylethylamine were added slowly. After 20 minutes stirring at room temperature the mixture was heated under reflux conditions for five hours. Afterwards the reaction was stirred at room temperature overnight. The reaction was stopped by adding $20 \mathrm{~mL}$ distilled water and $20 \mathrm{~mL} 2 \mathrm{M}$ hydrochloric acid. Excess acetonitrile was removed under reduced pressure and the resulting aqueous layer was extracted three times with $30 \mathrm{~mL}$ ethyl acetate. Subsequently, the combined organic layers were washed once with $20 \mathrm{~mL}$ saturated sodium chloride solution and once with $20 \mathrm{~mL}$ distilled water. Both aqueous washing solutions were extracted with $50 \mathrm{~mL}$ diethyl ether. All organic layers were combined, dried over magnesium sulfate, filtered and the solvent was removed under reduced pressure. Checking the raw product by TLC (ethyl acetate/ $n$-hexane, $1: 2$, $\mathrm{v} / \mathrm{v}$ ) showed that the product was of sufficient purity. Compound 3 was isolated as $6.59 \mathrm{~g}(14.2 \mathrm{mmol}$, quantitative yield, $R_{\mathrm{f}}=0.63$ ) of a slightly yellow solid. $T_{\mathrm{m}}: 245-256{ }^{\circ} \mathrm{C}$ (ethyl acetate/acetone; decomposition). Elemental analysis: $\mathrm{C}_{7} \mathrm{H}_{22} \mathrm{~B}_{20} \mathrm{ClN}_{3} \mathrm{~S}_{2}$, calculated (\%): C 18.12, H 4.78, N 9.05; found (\%): C 18.16, H 4.64, N 8.75. IR (KBr): $\tilde{\nu}=3446(\mathrm{~m}), 3072(\mathrm{~m})$, 3060 (m), 3050 (m), 2962 (w), 2617 (s), 2390 (w), 2091 (w), 1988 (w), $1718(\mathrm{w}), 1624(\mathrm{w}), 1562$ (w), 1501 (s), 1477 (s), 1456 (s), 1432 (m), 1312 (m), 1274 (s), 1252 (s), 1166 (m), 1150 (m), 1105 (w), $1067(\mathrm{~m}), 1036(\mathrm{w}), 992(\mathrm{~m}), 954(\mathrm{~m}), 920(\mathrm{w}), 863(\mathrm{~s}), 846$ (s), $806(\mathrm{~m}), 790(\mathrm{~m}), 773(\mathrm{~m}), 760(\mathrm{~m}), 732(\mathrm{~m}), 676(\mathrm{w}), 624$ $(\mathrm{w}), 576(\mathrm{w}), 507(\mathrm{w}), 376(\mathrm{w}) \mathrm{cm}^{-1} \cdot{ }^{1} \mathrm{H}$ NMR (acetone- $\left.d_{6}\right): \delta=$ 1.52-3.54 (br ${ }^{\mathrm{a}}, 18 \mathrm{H}, \mathrm{B}_{10} \mathrm{H}_{9}$ ), 3.82 (br, s, 4H, CH) ppm. ${ }^{13} \mathrm{C}\left\{{ }^{1} \mathrm{H}\right\}$ NMR (acetone- $\left.d_{6}\right): \delta=56.1$ (br, s, CH), $168.5\left(\mathrm{~s}, \mathrm{C}_{\mathrm{q}} \mathrm{Cl}\right), 182.6(\mathrm{~s}$, $\mathrm{C}_{\mathrm{q}} \mathrm{S}$ ) ppm. ${ }^{11} \mathrm{~B}\left\{{ }^{1} \mathrm{H}\right\}$ NMR (acetone- $d_{6}$ ): $\delta=-18.1$ (br, s, 2B), -16.8 (s, 2B), -13.8 (s, 4B), -12.8 (br $\left.{ }^{\mathrm{a}}, 4 \mathrm{~B}\right),-10.4$ (s, 2B), -5.9 (br, s, 4B), $-4.0(\mathrm{~s}, 2 \mathrm{~B}, \mathrm{BS}) \mathrm{ppm} .{ }^{11} \mathrm{~B}$ NMR (acetone- $\left.d_{6}\right): \delta=$ -17.5 (br $\left.{ }^{\mathrm{a}}, \mathrm{m}, 4 \mathrm{~B}\right),-13.2\left(\mathrm{br}^{\mathrm{a}}, \mathrm{m}, 8 \mathrm{~B}\right),-10.4\left(\mathrm{~d},{ }^{1} J_{\mathrm{BH}}=152 \mathrm{~Hz}\right.$, 2B), $-5.9\left(\mathrm{~d},{ }^{1} J_{\mathrm{BH}}=165 \mathrm{~Hz}, 4 \mathrm{~B}\right),-4.0$ (s, 2B, BS) ppm. ESI MS: positive mode, $\mathrm{C}_{7} \mathrm{H}_{23} \mathrm{~B}_{20} \mathrm{ClN}_{3} \mathrm{~S}_{2}, \mathrm{~m} / z$ calculated: 465.1 ; found: 465.4 (51\%, $\left.[\mathrm{M}+\mathrm{H}]^{+}\right) ; \mathrm{LiC}_{14} \mathrm{H}_{44} \mathrm{~B}_{40} \mathrm{Cl}_{2} \mathrm{~N}_{6} \mathrm{~S}_{4}, m / z$ calculated: 935.1; found: $935.6\left(100 \%,[2 \mathrm{M}+\mathrm{Li}]^{+}\right)$; negative mode, $\mathrm{C}_{7} \mathrm{H}_{22} \mathrm{~B}_{20} \mathrm{Cl}_{2} \mathrm{~N}_{3} \mathrm{~S}_{2}, \mathrm{~m} / z$ calculated: 499.5 ; found: 499.3 (38\%, $[\mathrm{M}+\mathrm{Cl}]^{-}$).

2-\{[4,6-Bis(1,7-dicarba-closo-dodecaboran-9-ylthio)-1,3,5-triazin2-yl]thio\}acetic acid (4). A $250 \mathrm{~mL}$ two-necked round bottom flask equipped with a condenser was charged with $2.01 \mathrm{~g}$ (4.33 mmol, 1.00 eq.) 3 and subsequently evacuated and purged with nitrogen three times. The starting material was dissolved in $150 \mathrm{~mL}$ of dry acetonitrile. $0.45 \mathrm{~mL}(0.60 \mathrm{~g}$, $6.46 \mathrm{mmol}, 1.49$ eq.) mercaptoacetic acid were added to this solution and the mixture was cooled to $0{ }^{\circ} \mathrm{C}$. Subsequently, $3.00 \mathrm{~mL}$ (2.28 g, $17.6 \mathrm{mmol}, 4.07 \mathrm{eq}$.) diisopropylethylamine were added to the reaction mixture and the mixture was stirred for $20 \mathrm{~min}$ at $0{ }^{\circ} \mathrm{C}$. After warming to room temperature, the mixture was stirred under reflux conditions for three hours. The reaction was stopped by adding $30 \mathrm{~mL}$ distilled water and $20 \mathrm{~mL} 2 \mathrm{M}$ hydrochloric acid. All volatile components were 
removed under reduced pressure and the resulting aqueous layer was extracted twice with $40 \mathrm{~mL}$ diethyl ether. The combined organic layers were washed twice with $20 \mathrm{~mL}$ distilled water, dried over magnesium sulfate, filtered and the solvent was removed under reduced pressure. The raw product was purified by column chromatography (ethyl acetate $/ n$-hexane, $1: 1$ to $100 \%$ ethyl acetate, v/v) and $600 \mathrm{mg}(1.15 \mathrm{mmol}, 27 \%$, $R_{\mathrm{f}}=0.18,100 \%$ ethyl acetate) of 4 were obtained as a slightly yellow solid. $T_{\mathrm{m}}$ : $175-177{ }^{\circ} \mathrm{C}$ (acetone). IR (KBr): $\tilde{\nu}=3431(\mathrm{w})$, 3054 (m), 2968 (m), 2926 (m), 2604 (s), 2092 (w), 1713 (s), 1471 (s), 1245(s), $1156(\mathrm{~m}), 1063$ (w), $990(\mathrm{w}), 951(\mathrm{~m}), 864(\mathrm{~m}), 844$ (s), $788(\mathrm{~m}), 756(\mathrm{~m}), 727(\mathrm{~m}), 675(\mathrm{w}), 625(\mathrm{w}), 460(\mathrm{w}) \mathrm{cm}^{-1}$. ${ }^{1} \mathrm{H}$ NMR (acetone- $\left.d_{6}\right): \delta=1.44-3.50\left(\mathrm{br}^{\mathrm{a}}, 18 \mathrm{H}, \mathrm{B}_{10} \mathrm{H}_{9}\right), 3.80(\mathrm{br}$, $\mathrm{s}, 4 \mathrm{H}, 4 \mathrm{CH}), 4.17$ (s, 2H, $\left.\mathrm{CH}_{2}\right), 11.28$ (br, s, 1H, COOH) ppm. ${ }^{13} \mathrm{C}\left\{{ }^{1} \mathrm{H}\right\}$ NMR (acetone- $\left.d_{6}\right): \delta=32.6\left(\mathrm{~s}, \mathrm{CH}_{2}\right), 56.1$ (br, s, CH), $169.7\left(\mathrm{~s}, \mathrm{C}_{\mathrm{q}} \mathrm{S}\right), 179.4\left(\mathrm{~s}, \mathrm{C}_{\mathrm{q}} \mathrm{OOH}\right), 179.6\left(\mathrm{~s}, \mathrm{C}_{\mathrm{q}} \mathrm{S}\right) \mathrm{ppm} .{ }^{11} \mathrm{~B}\left\{{ }^{1} \mathrm{H}\right\}$ NMR (acetone- $\left.d_{6}\right): \delta=-18.2(\mathrm{~s}, 2 \mathrm{~B}),-16.9(\mathrm{~s}, 2 \mathrm{~B}),-13.9(\mathrm{~s}, 4 \mathrm{~B})$, -12.7 (s, 4B), -10.4 (s, 2B), -5.9 (s, 4B), -3.8 (s, 2B, BS) ppm. ${ }^{11} \mathrm{~B}$ NMR (acetone- $\left.d_{6}\right): \delta=-17.6\left(\mathrm{br}^{\mathrm{a}}, 4 \mathrm{~B}\right),-13.3\left(\mathrm{br}^{\mathrm{a}}, 8 \mathrm{~B}\right)$, $-10.4\left(\mathrm{~d},{ }^{1} J_{\mathrm{BH}}=150 \mathrm{~Hz}, 2 \mathrm{~B}\right),-5.9\left(\mathrm{~d},{ }^{1} J_{\mathrm{BH}}=162 \mathrm{~Hz}, 4 \mathrm{~B}\right),-3.8$ (s, 2B, BS) ppm. ESI MS: positive mode, $\mathrm{C}_{9} \mathrm{H}_{26} \mathrm{~B}_{20} \mathrm{~N}_{3} \mathrm{O}_{2} \mathrm{~S}_{3}, \mathrm{~m} / \mathrm{z}$ calculated: 521.31608, found: $521.31583\left(100 \%,[\mathrm{M}+\mathrm{H}]^{+}\right)$.

[4,6-Bis(1,7-dicarba-closo-dodecaboran-9-ylthio)-1,3,5-triazin2-yl]glycine (5). A $100 \mathrm{~mL}$ two-necked round bottom flask equipped with a condenser was charged with $0.27 \mathrm{~g}$ (0.58 mmol, 1.00 eq.) 3 and $0.07 \mathrm{~g}$ (0.94 mmol, 1.61 eq.) glycine. The mixture was suspended in $30 \mathrm{~mL}$ acetonitrile. $0.13 \mathrm{~g}$ (3.25 mmol, 5.59 eq.) sodium hydroxide, dissolved in $20 \mathrm{~mL}$ distilled water, was added to this mixture. The mixture was heated to $85{ }^{\circ} \mathrm{C}$ and $20 \mathrm{~mL}$ acetonitrile and $15 \mathrm{~mL}$ ethyl acetate were added to obtain a clear solution. The reaction progress was monitored by TLC (acetone/ $n$-hexane/glacial acetic acid, $1: 1: 0.05, \mathrm{v} / \mathrm{v} / \mathrm{v})$. After one day, the reaction was stopped by adding $2 \mathrm{M}$ hydrochloric acid to receive a $\mathrm{pH}<7$. All organic solvents were removed under reduced pressure. The remaining aqueous layer was extracted four times with $50 \mathrm{~mL}$ diethyl ether. The combined organic layers were dried over magnesium sulfate, filtered and the solvent was removed under reduced pressure. After column chromatography (ethyl acetate $/ n$-hexane, $1: 1, \mathrm{v} / \mathrm{v}, 2.5 \%$ glacial acetic acid) $176 \mathrm{mg}$ (0.35 mmol, $60 \%, R_{\mathrm{f}}=0.14$ ) of 5 were isolated as a slightly yellow solid. $T_{\mathrm{m}}: 241-243{ }^{\circ} \mathrm{C}$ (ethyl acetate). IR (KBr): $\tilde{\nu}=3290$ (m), 3056 (s), 2927 (m), 2606 (s), 1714 (s), 1562 (s), 1521 (s), 1494 (s), 1415 (s), 1243 (s), 1176 (s), 1064 (m), 991 (m), $950(\mathrm{~m}), 850(\mathrm{~s}), 801(\mathrm{~m}), 757(\mathrm{w}), 730(\mathrm{~m}), 668(\mathrm{w}), 624(\mathrm{w})$, $450(\mathrm{w}) \mathrm{cm}^{-1} \cdot{ }^{1} \mathrm{H}$ NMR (acetone- $\left.d_{6}\right): \delta=1.40-3.60\left(\mathrm{br}^{\mathrm{a}}, 18 \mathrm{H}\right.$, $\left.\mathrm{B}_{10} \mathrm{H}_{9}\right), 3.71$ (br, s, $\left.4 \mathrm{H}, \mathrm{CH}\right), 4.30\left(\mathrm{~d},{ }^{3} J_{\mathrm{HH}}=6.3 \mathrm{~Hz}, 2 \mathrm{H}, \mathrm{CH}_{2}\right.$ ), $6.94\left(\mathrm{t},{ }^{3} J_{\mathrm{HH}}=6.0 \mathrm{~Hz}, 1 \mathrm{H}, \mathrm{NH}\right), 10.8(\mathrm{br}, \mathrm{s}, 1 \mathrm{H}, \mathrm{COOH}) \mathrm{ppm}$. ${ }^{13} \mathrm{C}\left\{{ }^{1} \mathrm{H}\right\}$ NMR (acetone- $\left.d_{6}\right): \delta=42.7\left(\mathrm{~s}, \mathrm{CH}_{2}\right), 55.7(\mathrm{br}, \mathrm{s}, \mathrm{CH})$, 55.8 (br, s, CH), $164.7\left(\mathrm{~s}, \mathrm{C}_{\mathrm{q}} \mathrm{NH}\right), 171.5\left(\mathrm{~s}, \mathrm{C}_{\mathrm{q}} \mathrm{S}\right), 179.9(\mathrm{~s}$, $\mathrm{C}_{\mathrm{q}} \mathrm{OOH}$ ) ppm. ${ }^{11} \mathrm{~B}\left\{{ }^{1} \mathrm{H}\right\} \mathrm{NMR}$ (acetone- $d_{6}$ ): $\delta=-18.6$ (s, 2B), -17.0 (s, 2B), -14.0 (s, 4B), -12.8 (s, 4B), -10.5 (s, 2B), -5.9 (s, $4 \mathrm{~B}),-3.3$ (s, 2B, BS) ppm. ${ }^{11} \mathrm{~B}$ NMR (acetone- $\left.d_{6}\right): \delta=-18.6\left(\mathrm{br}^{\mathrm{a}}\right.$, 2B), -17.0 (overlapping signals, 2B), -14.0 (br $\left.{ }^{\mathrm{a}}, 4 \mathrm{~B}\right),-12.8$ $\left(\mathrm{br}^{\mathrm{a}}, 4 \mathrm{~B}\right),-10.5\left(\mathrm{~d},{ }^{1} J_{\mathrm{BH}}=151 \mathrm{~Hz}, 2 \mathrm{~B}\right),-5.9\left(\mathrm{~d},{ }^{1} J_{\mathrm{BH}}=166 \mathrm{~Hz}\right.$, 4B), -3.3 (s, 2B, BS) ppm. ESI MS: positive mode,
$\mathrm{C}_{9} \mathrm{H}_{27} \mathrm{~B}_{20} \mathrm{~N}_{4} \mathrm{O}_{2} \mathrm{~S}_{2}, m / z$ calculated: 504.35497 , found: 504.35463 $\left(100 \%,[\mathrm{M}+\mathrm{H}]^{+}\right)$.

$N^{6}$-[4,6-Bis(1,7-dicarba-closo-dodecaboran-9-ylthio)-1,3,5-triazin2-yl]- $N^{2}$-(tert-butoxycarbonyl)-L-lysine (6). A $100 \mathrm{~mL}$ round bottom flask equipped with a condenser was charged with $0.20 \mathrm{~g}$ (0.43 mmol, 1.00 eq.) 3 and $0.12 \mathrm{~g}$ (0.49 mmol, 1.14 eq.) $N_{\alpha}$-(tert-butoxycarbonyl)-L-lysine. The mixture was suspended in a mixture of $20 \mathrm{~mL}$ acetonitrile and $25 \mathrm{~mL}$ distilled water. $0.07 \mathrm{~g}$ (1.75 mmol, 4.07 eq.) sodium hydroxide were added to this suspension and the mixture was stirred at room temperature for $30 \mathrm{~min}$, and then heated to $85^{\circ} \mathrm{C}$ for $18 \mathrm{~h}$. The reaction progress was monitored by TLC (ethyl acetate/ $n$-hexane, $1: 1, \mathrm{v} / \mathrm{v})$. After the reaction was finished the mixture was acidified with $1 \mathrm{M}$ hydrochloric acid and the resulting precipitate was immediately filtered off and washed with water until $\mathrm{pH} 7$ was reached. The precipitate was purified by column chromatography (acetone/n-hexane, $1: 1, \mathrm{v} / \mathrm{v}, 2.5 \%$ glacial acetic acid). $138 \mathrm{mg}\left(0.20 \mathrm{mmol}, 46.5 \%, R_{\mathrm{f}}=0.65\right)$ of 6 were isolated as a colourless solid. $T_{\mathrm{m}}: 178-180{ }^{\circ} \mathrm{C}$ (acetone). IR (KBr): $\tilde{\nu}=$ 3856 (w), 3455 (m), 3258 (m), 3138 (m), 3058 (m), 2980 (m), 2934 (m), 2864 (m), 2603 (s), 1698 (s), 1614 (s), 1569 (m), 1520 (s), $1500(\mathrm{~s}), 1452(\mathrm{~m}), 1435(\mathrm{~m}), 1410(\mathrm{~s}), 1369(\mathrm{~s}), 1307$ (m), 12477 (s), 1218 (m), 1201 (m), 1166 (s), 1117 (m), 1059 (m), $1022(\mathrm{w}), 994(\mathrm{w}), 954(\mathrm{~m}), 863(\mathrm{~s}), 850(\mathrm{~s}), 801(\mathrm{~m}), 760(\mathrm{~m})$, $731(\mathrm{~m}), 668(\mathrm{w}), 642(\mathrm{w}), 590(\mathrm{w}), 418(\mathrm{w}) \mathrm{cm}^{-1} \cdot{ }^{1} \mathrm{H}$ NMR (acetonitrile- $\left.d_{3}\right): \delta=1.40\left(\mathrm{~s}, 9 \mathrm{H}, \mathrm{C}\left(\mathrm{CH}_{3}\right)_{3}\right), 1.50-3.30\left(\mathrm{br}^{\mathrm{a}}, 18 \mathrm{H}\right.$, $\mathrm{B}_{10} \mathrm{H}_{9}$ ), 1.59 (br, m, 4H, $\mathrm{CH}_{2}$ ), 1.77 (br, m, 2H, $\mathrm{CH}_{2}$ ), 3.38 (br, $\mathrm{s}, 4 \mathrm{H}, \mathrm{CH}), 3.41\left(\mathrm{~m}, 2 \mathrm{H}, \mathrm{CH}_{2}\right), 4.04(\mathrm{~m}, 1 \mathrm{H}, \mathrm{CH}), 5.54\left(\mathrm{~d},{ }^{3} \mathrm{~J}_{\mathrm{HH}}=\right.$ $7.8 \mathrm{~Hz}, 1 \mathrm{H}, \mathrm{NH}), 6.20(\mathrm{~m}, 1 \mathrm{H}, \mathrm{NH}), 9.50(\mathrm{~s}, 1 \mathrm{H}, \mathrm{COOH}) \mathrm{ppm}$. ${ }^{13} \mathrm{C}\left\{{ }^{1} \mathrm{H}\right\}$ NMR (acetonitrile- $\left.d_{3}\right): \delta=23.9\left(\mathrm{~s}, \mathrm{CH}_{2}\right), 28.6(\mathrm{~s}$, $\left.\mathrm{C}\left(\mathrm{CH}_{3}\right)_{3}\right), 30.2\left(\mathrm{~s}, \mathrm{CH}_{2}\right), 32.1\left(\mathrm{~s}, \mathrm{CH}_{2}\right), 41.2\left(\mathrm{~s}, \mathrm{CH}_{2}\right), 54.4$ (s, $\mathrm{CH}), 55.9$ (br, s, CH), 56.0 (br, s, CH), $79.9\left(\mathrm{~s}, C_{\mathrm{q}}\left(\mathrm{CH}_{3}\right)_{3}\right), 156.7$ $\left(\mathrm{s}, \mathrm{C}_{\mathrm{q}} \mathrm{S}\right), 174.5\left(\mathrm{~s}, \mathrm{C}_{\mathrm{q}}\right), 178.5\left(\mathrm{~s}, \mathrm{C}_{\mathrm{q}} \mathrm{O}\right), 179.6\left(\mathrm{~s}, \mathrm{C}_{\mathrm{q}} \mathrm{OOH}\right) \mathrm{ppm}$. ${ }^{11} \mathrm{~B}\left\{{ }^{1} \mathrm{H}\right\}$ NMR (acetonitrile- $d_{3}$ ): $\delta=-18.4(\mathrm{~s}, 2 \mathrm{~B}),-17.0(\mathrm{~s}, 2 \mathrm{~B})$, -14.1 (s, 4B), -12.9 (s, 4B), -10.6 (s, 2B), -6.0 (s, 4B), -3.5 (s, $2 \mathrm{~B}, \mathrm{BS}) \mathrm{ppm} .{ }^{11} \mathrm{~B}$ NMR (acetonitrile- $\left.d_{3}\right): \delta=-18.4\left(\mathrm{br}^{\mathrm{a}}, 2 \mathrm{~B}\right)$, $-17.0\left(\mathrm{br}, \mathrm{d},{ }^{1} J_{\mathrm{BH}}=192 \mathrm{~Hz}, 2 \mathrm{~B}\right),-13.5\left(\mathrm{br}^{\mathrm{a}}, 8 \mathrm{~B}\right),-10.6(\mathrm{~d}$, $\left.{ }^{1} J_{\mathrm{BH}}=154 \mathrm{~Hz}, 2 \mathrm{~B}\right),-6.0\left(\mathrm{~d},{ }^{1} J_{\mathrm{BH}}=166 \mathrm{~Hz}, 4 \mathrm{~B}\right),-3.5(\mathrm{~s}, 2 \mathrm{~B}, \mathrm{BS})$ ppm. Detailed assignment of all spectroscopic data is given in the ESI. $\dagger$ ESI MS: Negative mode, $\mathrm{C}_{18} \mathrm{H}_{42} \mathrm{~B}_{20} \mathrm{~N}_{5} \mathrm{O}_{4} \mathrm{~S}_{2}, m / z$ calculated: 673.46669 , found: $673.46701\left(100 \%,[\mathrm{M}-\mathrm{H}]^{-}\right)$.

2,4,6-Tris(1,7-dicarba-closo-dodecaboran-9-ylthio)-1,3,5-triazine (7) and 4,6-bis(1,7-dicarba-closo-dodecaboran-9-ylthio)-1,3,5-triazine-2(1H)-one (8) were obtained as by-products in several reactions (Table S2, ESI); details, molecular structures and analytical data are given in the ESI. $\dagger$

\section{Peptide synthesis}

Materials. 9-Fluorenylmethoxycarbonyl (Fmoc)- and tertbutyloxycarbonyl (Boc)-protected amino acids were purchased from Orpegen OPC (Heidelberg, Germany), Iris Biotech (Marktredwitz, Germany) and Sigma-Aldrich (Taufkirchen, Germany). NovaSyn TGR R resin was from Novabiochem (Darmstadt, Germany) and 1-hydroxybenzotriazole (HOBt), $N, N^{\prime}-$ diisopropylcarbodiimide (DIC) and ethyl 2-cyano-2-(hydroxyimino)acetate (Oxyma) were obtained from Iris Biotech. 
Acetonitrile (ACN) was from VWR (Darmstadt, Germany) and dimethylformamide (DMF) and dichloromethane (DCM) were obtained from Biosolve (Valkenswaard, The Netherlands). Dimethylsulfoxide (DMSO), hydrazine, piperidine, thioanisole (TA) and trifluoroacetic acid (TFA) were purchased from SigmaAldrich, thiocresole (TC) was from Alfa Aesar (Ward Hill, MA, USA) and diethyl ether was from Merck (Darmstadt, Germany).

Synthesis. Synthesis of peptides was performed by a combination of automated solid phase peptide synthesis (SPPS) using a SYRO I peptide synthesiser (MultiSynTech, Bochum, Germany) and manual SPPS. The Fmoc/tert-butyl $\left({ }^{t} \mathrm{Bu}\right)$ strategy was applied and a NovaSyn TGR R resin $(15 \mu$ mol scale, $0.19 \mathrm{mmol} \mathrm{g}^{-1}$ ) was used to obtain peptides with C-terminal amidation. All amino acids were $N$ - $\alpha$-Fmoc-protected, except of the N-terminal amino acid of the peptide conjugates, which was $N$ - $\alpha$-Boc-protected. Full-length peptide backbones were prepared by automated SPPS and for the introduction of derivative 4, Fmoc-L-Lys(Dde)-OH was used respectively at positions 4, 18 and 22. In the automated synthesis, an 8-fold molar excess of amino acid was coupled with equimolar amounts of Oxyma and DIC (8 equiv., $120 \mu \mathrm{mol}$ ) in DMF for $2 \times 40 \mathrm{~min}$. Cleavage of the N-terminal Fmoc protecting group was performed with $40 \%(\mathrm{v} / \mathrm{v})$ piperidine in DMF for 3 min and again $20 \%(\mathrm{v} / \mathrm{v})$ piperidine in DMF for $10 \mathrm{~min}$. The 4,4-dimethyl-2,6dioxocyclohex-1-ylidenethyl (Dde) protecting group at the $\varepsilon$ amino group of lysine residues was removed with $3 \%(\mathrm{v} / \mathrm{v})$ hydrazine in DMF for $12 \times 10 \mathrm{~min}$. Derivative 4 was coupled manually in 3 -fold molar excess per free amino group with HOBt and DIC (5 equiv. per free amino group) in DMF overnight at room temperature. Cleavage from the resin and simultaneous side chain deprotection was accomplished by incubating the resin with a mixture of TFA/TA/TC $(90: 5: 5, \mathrm{v} / \mathrm{v})$ for $2 \mathrm{~h}$ and a subsequent precipitation of the crude peptide in icecold diethyl ether. The peptide was washed and dissolved in $\mathrm{ACN} / \mathrm{H}_{2} \mathrm{O}$ and subsequently lyophilised. Purification of the crude peptides was achieved by preparative reversed phase (RP)-HPLC using a Phenomenex Aeris ${ }^{\circledR}$ 3.6u PEPTIDE XB-C18 $(250 \mathrm{~mm} \times 21.2 \mathrm{~mm}, 3.6 \mu \mathrm{m}, 100 \AA)$ column with a flow rate of

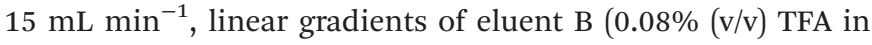
ACN $)$ in eluent A $(0.1 \%(\mathrm{v} / \mathrm{v})$ TFA in water $)$ and detection at $\lambda=220 \mathrm{~nm}$. The purity of the peptides was determined by analytical RP-HPLC using a Phenomenex Jupiter® $4 \mathrm{u}$ Proteo $\mathrm{C} 1290 \AA\left(250 \mathrm{~mm} \times 4.6 \mathrm{~mm}, 4 \mu \mathrm{m}, 90 \AA, 0.6 \mathrm{~mL} \mathrm{~min}{ }^{-1}\right)$ column. MALDI-ToF mass spectrometry (UltraflexIII, Bruker, Bremen, Germany) and ESI Ion-trap (HCT, Bruker Daltonics) or ESI Orbitrap (Orbitrap Elite, Thermo Scientific) mass spectrometry were used to verify the identity of the pure peptides. The observed masses were in agreement with the calculated masses and a purity of $>95 \%$ was obtained for all peptides in the analytical RP-HPLC.

\section{Biological methods}

Materials. Dulbecco's modified Eagle medium (DMEM), Dulbecco's phosphate buffered saline (DPBS), Ham's F12 and trypsin/EDTA were purchased from Lonza. Fetal calf serum (FCS) was obtained from Biochrom (Berlin, Germany), hygro- mycin B was purchased from InvivoGen (San Diego, CA, USA), G418-sulfate was from Merck. Opti-MEM ${ }^{\circledR}$ was purchased from Life Technologies (Carlsbad, CA, USA), Hoechst 33342 and $\mathrm{LiCl}$ were purchased from Sigma-Aldrich. $\left[2{ }^{3} \mathrm{H}\right]$-myo-inositol was obtained from PerkinElmer (Waltham, MA, USA), and bovine serum albumin (BSA) was from Roth (Karlsruhe, Germany).

Cell culture. All cell lines were maintained under humidified atmosphere at $37{ }^{\circ} \mathrm{C}$ and $5 \% \mathrm{CO}_{2}$ in $75 \mathrm{~cm}^{2}$ cell culture flasks. HEK293 cells stably expressing the $\mathrm{hY}_{1} \mathrm{R}$, C-terminally fused to the enhanced yellow fluorescent protein (eYFP), were cultured in DMEM/Ham's F12 (1:1, v/v) supplemented with $15 \%(\mathrm{v} / \mathrm{v})$ FCS and hygromycin $\left(100 \mu \mathrm{g} \mathrm{mL} \mathrm{m}^{-1}\right)$. COS-7 cells, stably coexpressing the $\mathrm{hY}_{1} \mathrm{R}$, C-terminally fused to eYFP, and the chimeric $G$ protein $G \alpha_{\Delta 6 q i 4 m y r}$, were cultured in DMEM high glucose supplemented with $10 \%(\mathrm{v} / \mathrm{v})$ FCS, hygromycin B $\left(133 \mu \mathrm{g} \mathrm{mL}^{-1}\right)$ and $\mathrm{G} 418$-sulfate $\left(1.5 \mathrm{mg} \mathrm{mL}^{-1}\right)$.

Inositol phosphate accumulation assay. Inositol phosphate (IP) accumulation assay for the determination of receptor activation was carried out as described previously. ${ }^{63}$ Briefly, COS-7 cells stably co-transfected with the $\mathrm{hY}_{1} \mathrm{R}$ and the chimeric $\mathrm{G}$ protein $\mathrm{G} \alpha_{\Delta 6 \mathrm{q} i 4 \mathrm{myr}}$ were seeded in 48 -well plates (60000 cells per well) and cultured overnight. Cells were labeled with $\left[2-{ }^{3} \mathrm{H}\right]$-myo-inositol $\left(2 \mu \mathrm{Ci} \mathrm{mL}{ }^{-1}\right)$ in medium without penicillin and streptomycin overnight and stimulated with different peptide concentrations in DMEM supplemented with $10 \mathrm{mM}$ $\mathrm{LiCl}$ and $0.1 \%(\mathrm{w} / \mathrm{v})$ BSA for $1 \mathrm{~h}$ at $37{ }^{\circ} \mathrm{C}$. Compounds were typically tested in a concentration range from $10^{-5} \mathrm{M}$ to $10^{-11}$ $\mathbf{M}$ in duplicates. Radioactive IP species were isolated by anionexchange chromatography and measured by scintillation counting. Data analysis was performed with GraphPad Prism 5.03. Obtained raw dpm values were normalised to NPY and $\mathrm{EC}_{50}$ and $\mathrm{pEC}_{50}$ values were calculated from sigmoidal concentration-response curves. Each peptide was tested at least two times independently.

Internalisation studies. HEK293 cells stably transfected with the $\mathrm{hY}_{1} \mathrm{R}$ fused to eYFP, were seeded into ibiTreat 8-well $\mu$-slides (ibidi, Martinsried, Germany) at a density of 300000 cells per well and cultured for $24 \mathrm{~h}$ until the cells reached confluency. The medium was aspirated and the cells were starved in $200 \mu \mathrm{L}$ Opti-MEM ${ }^{\circledR}$ with $1 \mu \mathrm{L}$ nuclear stain Hoechst 33342 $\left(0.5 \mathrm{mg} \mathrm{mL} \mathrm{mL}^{-1}\right.$ ) for $30 \mathrm{~min}$ under standard incubation conditions. For non-stimulated cells, the solution was aspirated and $200 \mu \mathrm{L}$ Opti-MEM ${ }^{\circledR}$ were added. For testing the receptor internalisation of the NPY analogues, the starving medium was aspirated and $200 \mu \mathrm{L}$ Opti-MEM ${ }^{\circledR}$ containing $100 \mathrm{nM}$ peptide conjugate were added to the cells. After $1 \mathrm{~h}$ of stimulation at $37^{\circ} \mathrm{C}$, the cells were washed once and maintained in Opti-MEM ${ }^{\circledR}$. A Zeiss Axio Observer microscope with an ApoTome.2 Imaging System and a $63 \times$ immersion oil objective was used for fluorescence image acquisition. The nuclear stain Hoechst 33342 was visualised by the DAPI filter (excitation 335-383 nm; emission $420-470 \mathrm{~nm}$ ) and the eYFP-tag on the receptor by the YFP filter (excitation 488-512 nm; emission $520-550 \mathrm{~nm}$ ). Image processing was performed with Zeiss ZEN 2 software. 


\section{Conclusions}

A modular approach was used for the synthesis of meta-carboranyl-substituted $s$-triazines with carboxylic acid functions, namely the thioglycolic acid derivative 4, the glycine derivative 5 , and the $N_{\alpha}$-Boc-L-lysine derivative $\mathbf{6}$, which can be coupled with suitable biomolecules for selective tumour targeting as was demonstrated here for compound 4. The peptide conjugate of one thioglycolic acid derivative 4 with breasttumour selective $\left[\mathrm{F}^{7}, \mathrm{P}^{34}\right]$-NPY, $\left[\mathrm{K}^{4}\left(4^{\prime}\right), \mathrm{F}^{7}, \mathrm{P}^{34}\right]$-NPY, exhibits full agonism, while incorporation of more than one derivative 4 leads to a significant loss of activity of the peptide conjugates at the human $\mathrm{Y}_{1}$ receptor. It can be speculated that the hydrophobicity of the conjugates with more than one derivative 4 is too high and leads thereby to a hydrophobic collapse of the conjugate. More hydrophilic derivatives could potentially result in higher activity of the peptide conjugates. Further potential is offered by the L-lysine derivative $\mathbf{6}$, which might be directly employed as an artificial amino acid in the preparation of peptides, proteins or even antibodies. Furthermore, deprotection of the tert-butoxycarbonyl group in $\mathbf{6}$ will allow further derivatisation, for example for increasing the water solubility or the introduction of an imaging agent. ${ }^{9,64}$

\section{Conflicts of interest}

There are no conflicts to declare.

\section{Acknowledgements}

We thank Ramona Oehme, Dr Susan Billig, Dr Claudia Birkemeyer and Regina Reppich for measuring the mass spectra, Manuela Roßberg for elemental analysis, Stefanie Märcker-Recklies and Ines Rein for recording the infrared spectra, Ronny Müller for support in peptide synthesis and Kristin Löbner for cell culture support.

\section{Notes and references}

1 G. L. Locher, Am. J. Roentgenol. Radium Ther., 1936, 36, $1-18$.

2 (a) R. F. Barth, P. Mi and W. Yang, Cancer Commun., 2018, 38, 1-15; (b) G. Calabrese, A. Daou, E. Barbu and J. Tsibouklis, Drug Discovery Today, 2018, 23, 63-75; (c) I. B. Sivaev and V. V. Bregadze, Eur. J. Inorg. Chem., 2009, 11, 1433-1450; (d) G. W. Kabalka, Expert Opin. Ther. Pat., 1998, 8, 545-551; (e) H. Hatanaka, J. Neurol., 1975, 209, 81-94.

3 R. F. Barth, A. H. Soloway and R. G. Fairchild, Cancer Res., 1990, 50, 1061-1070.

4 A. H. Soloway, W. Tjarks, B. A. Barnum, F.-G. Rong, R. F. Barth, I. M. Codogni and J. G. Wilson, Chem. Rev., 1998, 98, 1515-1562.
5 M. F. Hawthorne, Angew. Chem., Int. Ed., 1993, 32, 950-984, (Angew. Chem., 1993, 105, 997-1033).

6 (a) V. F. Sears, Neutron News, 1992, 3, 26-37; (b) W. Petry and J. Neuhaus, Phys. J., 2007, 6, 31-37.

7 X. Q. Pan, H. Wang, S. Shukla, M. Sekido, D. M. Adams, W. Tjarks, R. F. Barth and R. J. Lee, Bioconjugate Chem., 2002, 13, 435-442.

8 (a) S. Shukla, G. Wu, M. Chatterjee, W. Yang, M. Sekido, L. A. Diop, R. Müller, J. J. Sudimack, R. J. Lee, R. F. Barth and W. Tjarks, Bioconjugate Chem., 2003, 14, 158-167; (b) Y. Iguchi, H. Michiue, M. Kitamatsu, Y. Hayashi, F. Takenaka, T.-i. Nishiki and H. Matsui, Biomaterials, 2015, 56, 10-17; (c) A. Doi, S. Kawabata, K. Iida, K. Yokoyama, Y. Kajimoto, T. Kuroiwa, T. Shirakawa, M. Kirihata, S. Kasaoka, K. Maruyama, H. Kumada, Y. Sakurai, S.-i. Masunaga, K. Ono and S.-I. Miyatake, J. Neurooncol., 2008, 87, 287-294; (d) I. Romero-Canelón, B. Phoenix, A. Pitto-Barry, J. Tran, J. J. Soldevila-Barreda, N. Kirby, S. Green, P. J. Sadler and N. P. E. Barry, J. Organomet. Chem., 2015, 796, 17-25; (e) K. Kettenbach, H. Schieferstein, C. Grunewald, D. Iffland, L. M. Reffert, G. Hampel, C. L. Schütz, N. H. Bings and T. L. Ross, Radiochim. Acta, 2015, 103, 799-809; $(f)$ W. Mier, D. Gabel, U. Haberkorn and M. Eisenhut, Z. Anorg. Allg. Chem., 2004, 630, 1258-1262.

9 R. Dubey, S. Kushal, A. Mollard, L. Vojtovich, P. Oh, M. D. Levin, J. E. Schnitzer, I. Zharov and B. Z. Olenyuk, Bioconjugate Chem., 2015, 26, 78-89.

10 B. Feng, K. Tomizawa, H. Michiue, S.-I. Miyatake, X.-J. Han, A. Fujimura, M. Seno, M. Kirihata and H. Matsui, Biomaterials, 2009, 30, 1746-1755.

11 H. Michiue, Y. Sakurai, N. Kondo, M. Kitamatsu, F. Bin, K. Nakajima, Y. Hirota, S. Kawabata, T.-i. Nishiki, I. Ohmori, K. Tomizawa, S.-I. Miyatake, K. Ono and H. Matsui, Biomaterials, 2014, 35, 3396-3405.

12 C.-H. Lai, Y.-C. Lin, F.-I. Chou, C.-F. Liang, E.-W. Lin, Y.-J. Chuang and C.-C. Lin, Chem. Commun., 2012, 48, 612614.

13 R. Otero, S. Seoane, R. Sigüeiro, A. Y. Belorusova, M. A. Maestro, R. Pérez-Fernández, N. Rochel and A. Mouriño, Chem. Sci., 2016, 7, 1033-1037.

14 D. J. Worm, S. Els-Heindl, M. Kellert, R. Kuhnert, S. Saretz, J. Koebberling, B. Riedl, E. Hey-Hawkins and A. G. BeckSickinger, J. Pept. Sci., 2018, 32, e3119.

15 G. Ciofani, V. Raffa, A. Menciassi and A. Cuschieri, Nanoscale Res. Lett., 2008, 4, 113-121.

16 P. J. Kueffer, C. A. Maitz, A. A. Khan, S. A. Schuster, N. I. Shlyakhtina, S. S. Jalisatgi, J. D. Brockman, D. W. Nigg and M. F. Hawthorne, Proc. Natl. Acad. Sci. U. S. A., 2013, 110, 6512-6517.

17 (a) J. Chadwick and M. Goldhaber, Nature, 1935, 135, 6565; (b) H. J. Taylor and M. Goldhaber, Nature, 1935, 135, 341-341.

18 Y. Hattori, S. Kusaka, M. Mukumoto, K. Uehara, T. Asano, M. Suzuki, S.-i. Masunaga, K. Ono, S. Tanimori and M. Kirihata, J. Med. Chem., 2012, 55, 6980-6984. 
19 T. Hartman and J. Carlsson, Radiother. Oncol., 1994, 31, 61-75.

20 V. M. Ahrens, R. Frank, S. Stadlbauer, A. G. Beck-Sickinger and E. Hey-Hawkins, J. Med. Chem., 2011, 54, 2368-2377.

21 (a) K. Y. Choi, G. Saravanakumar, J. H. Park and K. Park, Colloid Surf., B, 2012, 99, 82-94; (b) S. Agosteo, P. Colautti, J. Esposito, A. Fazzi, M. V. Introini and A. Pola, Appl. Radiat. Isot., 2011, 69, 1664-1667; (c) H. Kumada, A. Matsumura, H. Sakurai, T. Sakae, M. Yoshioka, H. Kobayashi, H. Matsumoto, Y. Kiyanagi, T. Shibata and H. Nakashima, Appl. Radiat. Isot., 2014, 88, 211-215; (d) E. Durisi, K. Alikaniotis, O. Borla, F. Bragato, M. Costa, G. Giannini, V. Monti, L. Visca, G. Vivaldo and A. Zanini, Appl. Radiat. Isot., 2015, 106, 63-67; (e) T. Onishi, H. Kumada, K. Takada, F. Naito, T. Kurihara and T. Sakae, Appl. Radiat. Isot., 2018, 140, 5-11.

22 C.-H. Lee, H.-G. Lim, J.-D. Lee, Y.-J. Lee, J. Ko, H. Nakamura and S. Ook Kang, Appl. Organomet. Chem., 2003, 17, 539-548.

23 Y. Azev, I. Slepukhina and D. Gabel, Appl. Radiat. Isot., 2004, 61, 1107-1110.

24 (a) H. Nakamura, A. Shoji, A. Takeuchi, H. S. Ban, J.-D. Lee and S. O. Kang, Aust. J. Chem., 2011, 64, 1430-1437; (b) J.-D. Lee, S.-J. Cho, S.-H. Kim, G.-Y. Chai and C.-H. Lee, Bull. Korean Chem. Soc., 2012, 33, 3136-3138; (c) C.-H. Lee, J. H. Yun, G. F. Jin, Y. J. Jung, S. O. Kang and J.-D. Lee, KR20090016794(A), 2009, 1-16.

25 J.-D. Lee, S. Y. Kim and S. O. Kang, Biochem. Biophys. J. Neutron Ther. Cancer Treatments (BBJNTCT), 2014, 2, 8-12.

26 C.-H. Lee, G. F. Jin, H.-S. Kim, H. Nakamura and J.-D. Lee, Bull. Korean Chem. Soc., 2008, 29, 697-700.

27 C.-H. Lee, G. Jin, J. Yoon, S. Kim, J.-D. Lee, H. Nakamura and S. O. Kang, Synthesis, 2008, 1193-1200.

28 C.-H. Lee, G. F. Jin, J. H. Yoon, Y. J. Jung, J.-D. Lee, S. Cho, H. Nakamura and S. O. Kang, Tetrahedron Lett., 2008, 49, 159-164.

29 S. Ronchi, D. Prosperi, F. Compostella and L. Panza, Synlett, 2004, 1007-1010.

30 J. C. Reubi, M. Gugger and B. Waser, Cancer Res., 2001, 61, 4636-4641.

31 I. U. Khan, D. Zwanziger, I. Böhme, M. Javed, H. Naseer, S. W. Hyder and A. G. Beck-Sickinger, Angew. Chem., Int. Ed., 2010, 49, 1155-1158, (Angew. Chem., 2010, 122, 11741177).

32 (a) F. Kallmeier, T. Irrgang, T. Dietel and R. Kempe, Angew. Chem., Int. Ed., 2016, 55, 11806-11809, (Angew. Chem., 2016, 128, 11984-11988); (b) T. Balakrishnan, E. Murugan and A. Siva, Appl. Catal., A, 2004, 273, 89-97; (c) N. Klee, P. E. Wong, B. Baragaña, F. E. Mazouni, M. A. Phillips, M. P. Barrett and I. H. Gilbert, Bioorg. Med. Chem. Lett., 2010, 20, 4364-4366; (d) J. Salabert, R. M. Sebastián and A. Vallribera, Chem. Commun., 2015, 51, 14251-14254; (e) Z. J. Kamiński, B. Kolesińska, J. Kolesińska, G. Sabatino, M. Chelli, P. Rovero, M. Błaszczyk, M. L. Główka and A. M. Papini, J. Am. Chem. Soc., 2005, 127, 16912-16920; (f) G.-H. Kuo, A. Deangelis, S. Emanuel, A. Wang, Y. Zhang, P. J. Connolly, X. Chen, R. H. Gruninger, C. Rugg, A. Fuentes-Pesquera, S. A. Middleton, L. Jolliffe and W. V. Murray, J. Med. Chem., 2005, 48, 4535-4546; (g) A. Olczak, M. Blaszczyk, M. L. Glówka, B. Kolesińska and Z. J. Kamiński, Pol. J. Chem., 2008, 82, 1413-1423; (h) C. Zhu, C. Deng, J.-Y. Cao and Y.-Z. Wang, Polym. Degrad. Stab., 2015, 121, 42-50; (i) K. Venkataraman and D. R. Wagle, Tetrahedron Lett., 1979, 32, 3037-3040; (j) J. K. Srivastava, P. Dubey, S. Singh, H. R. Bhat, M. K. Kumawat and U. P. Singh, RSC Adv., 2015, 5, 1409514102.

33 K. Arya and A. Dandia, Bioorg. Med. Chem. Lett., 2007, 17, 3298-3304.

34 C. Shen, T. Sheng, Q. Zhu, S. Hu and X. Wu, CrystEngComm, 2012, 14, 3189-3189.

35 J. R. Dudley, J. T. Thurston, F. C. Schaefer, D. HolmHansen, C. J. Hull and P. Adams, J. Am. Chem. Soc., 1951, 73, 2986-2990.

36 (a) B. Bitter and H. Zollinger, Angew. Chem., 1958, 70, 246247; (b) D. M. Tigelaar, A. E. Palker, C. M. Jackson, K. M. Anderson, J. Wainright and R. F. Savinell, Macromolecules, 2009, 42, 1888-1896.

37 C. Afonso, N. Lourenco and A. Rosatella, Molecules, 2006, 11, 81-102.

38 V. I. Bregadze, Chem. Rev., 1992, 92, 209-223.

39 D. Grafstein and J. Dvorak, Inorg. Chem., 1963, 2, 11281133.

40 (a) M. A. Fox, W. R. Gill, P. L. Herbertson, J. A. H. MacBride and K. Wade, Polyhedron, 1996, 15, 565-571; (b) J. Yoo, J.-W. Hwang and Y. Do, Inorg. Chem., 2001, 40, 568570.

41 (a) P. Kaszynski, Collect. Czech. Chem. Commun., 1999, 64, 895-926; (b) Z. Juan, H. Pengcheng, C. Gong and Z. Maosheng, Prog. Chem., 2012, 24, 556-567; (c) L. I. Zakharkin and V. N. Kalinin, Izv. Akad. Nauk. SSSR, 1965, 7, 1287; (d) J. A. Potenza, W. N. Lipscomb, G. D. Vickers and H. Schröder, J. Am. Chem. Soc., 1966, 88, 628-629.

42 V. N. Kalinin and V. A. Ol'shevskaya, Russ. Chem. Bull. Int. Ed., 2008, 57, 815-836; also published in Russian in Izvestiya Akademii Nauk. Seriya Khimicheskaya, 2008, 3, 801822.

43 A. M. Spokoyny, C. D. Lewis, G. Teverovskiy and S. L. Buchwald, Organometallics, 2012, 31, 8478-8481.

44 (a) J. Plešek, Z. Janoušek and S. Heřmánek, Collect. Czech. Chem. Commun., 1978, 43, 1332-1338; (b) R. Frank, S. Boehnke, A. Aliev and E. Hey-Hawkins, Polyhedron, 2012, 39, 9-13; (c) J. M. Oliva and C. Viñas, J. Mol. Struct., 2000, 556, 33-42; (d) J. Plešek and S. Heřmánek, Collect. Czech. Chem. Commun., 1981, 46, 687-693.

45 S. Boehnke, S. Saretz, M. Kellert and E. Hey-Hawkins, Biochem. Biophys. J. Neutron Ther. Cancer Treatments (BBJNTCT), 2013, 1, 22-27.

46 L. I. Zakharkin and I. V. Pisareva, Phosphorus Sulfur, 1984, 20, 357-370. 
47 P. Tsitsa, E. Antoniadou-Vyza, S. J. Hamodrakas, E. E. Eliopoulos, A. Tsantili-Kakoulidou, E. LadaHytiroglou, C. Roussakis, I. Chinou, A. Hempel, N. Camerman, F. P. Ottensmeyer and D. A. Vanden Berghe, Eur. J. Med. Chem., 1993, 28, 149-158.

48 V. M. Ahrens, R. Frank, S. Boehnke, C. L. Schütz, G. Hampel, D. S. Iffland, N. H. Bings, E. Hey-Hawkins and A. G. Beck-Sickinger, ChemMedChem, 2015, 10, 164-172.

49 S. M. F. Vilela, D. Ananias, P. Silva, M. Nolasco, L. D. Carlos, V. de Zea Bermudez, J. Rocha, J. P. C. Tomé and F. A. Almeida Paz, CrystEngComm, 2014, 16, 8119-8137.

50 R. Frank, V. Ahrens, S. Boehnke, S. Hofmann, M. Kellert, S. Saretz, S. Pandey, M. Sárosi, Á. Bartók, A. G. BeckSickinger and E. Hey-Hawkins, Pure Appl. Chem., 2015, 87, 163-171.

51 R. Frank, V. M. Ahrens, S. Boehnke, A. G. Beck-Sickinger and E. Hey-Hawkins, ChemBioChem, 2016, 17, 308-317.

52 S. Stadlbauer, R. Frank, M. Scholz, S. Boehnke, V. M. Ahrens, A. G. Beck-Sickinger and E. Hey-Hawkins, Pure Appl. Chem., 2012, 84, 2289-2298.

53 R. Frank and E. Hey-Hawkins, J. Organomet. Chem., 2015, 798, 46-50.

54 (a) R. K. Harris, E. D. Becker, S. M. Cabral de Menezes, R. Goodfellow and P. Granger, Pure Appl. Chem., 2001, 73,
1795-1818; (b) R. K. Harris, E. D. Becker, S. M. Cabral de Menezes, R. Goodfellow and P. Granger, Solid State Nucl. Magn. Reson., 2002, 22, 458-483.

55 MestReNova, v12.00-20080, Mestrelab Research S.L., 2017.

56 CrysAlis Pro: Data Collection and Data Reduction Software Package, Rigaku Oxford Diffraction.

57 SCALE3 ABSPACK: Empirical Absorption Correction using Sperical Harmonics.

58 G. M. Sheldrick, Acta Crystallogr., Sect. A: Found. Adv., 2015, 71, 3-8.

59 G. M. Sheldrick, Acta Crystallogr., Sect. C: Struct. Chem., 2015, 71, 3-8.

60 L. J. Farrugia, J. Appl. Crystallogr., 1997, 30, 565-565.

61 K. Brandenburg, Diamond, v4.5.3, Crystal Impact GbR, Bonn, Germany.

62 Mercury, v4.1.0, The Cambridge Crystallographic Data Centre, 2019.

63 S. Hofmann, R. Frank, E. Hey-Hawkins, A. G. BeckSickinger and P. Schmidt, Neuropeptides, 2013, 47, 59-66.

64 (a) A. Toppino, M. E. Bova, S. Geninatti Crich, D. Alberti, E. Diana, A. Barge, S. Aime, P. Venturello and A. Deagostino, Chem. - Eur. J., 2013, 19, 721-728; (b) A. R. Genady, J. A. Ioppolo, M. M. Azaam and M. E. ElZaria, Eur. J. Med. Chem., 2015, 93, 574-583. 